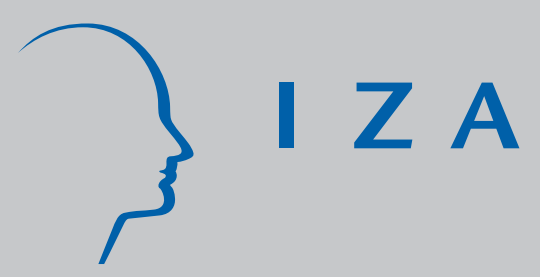

IZA DP No. 2619

The Effects of Marriage on Couples' Allocation of Time Between Market and Non-Market Hours

AbdelRahmen El Lahga

Nicolas Moreau

February 2007 


\title{
The Effects of Marriage on Couples' Allocation of Time Between Market and Non-Market Hours
}

\author{
AbdelRahmen El Lahga \\ Institut Supérieur de Gestion de Tunis \\ Nicolas Moreau \\ University of Toulouse 1, GREMAQ and IZA
}

\section{Discussion Paper No. 2619 \\ February 2007}

IZA

P.O. Box 7240

53072 Bonn

Germany

\author{
Phone: +49-228-3894-0 \\ Fax: +49-228-3894-180 \\ E-mail: iza@iza.org
}

\begin{abstract}
Any opinions expressed here are those of the author(s) and not those of the institute. Research disseminated by IZA may include views on policy, but the institute itself takes no institutional policy positions.

The Institute for the Study of Labor (IZA) in Bonn is a local and virtual international research center and a place of communication between science, politics and business. IZA is an independent nonprofit company supported by Deutsche Post World Net. The center is associated with the University of Bonn and offers a stimulating research environment through its research networks, research support, and visitors and doctoral programs. IZA engages in (i) original and internationally competitive research in all fields of labor economics, (ii) development of policy concepts, and (iii) dissemination of research results and concepts to the interested public.
\end{abstract}

IZA Discussion Papers often represent preliminary work and are circulated to encourage discussion. Citation of such a paper should account for its provisional character. A revised version may be available directly from the author. 
IZA Discussion Paper No. 2619

February 2007

\section{ABSTRACT}

\section{The Effects of Marriage on Couples' Allocation of Time Between Market and Non-Market Hours}

We evaluate the effects of the transition from cohabitation to marriage on household domestic and market work hours using a sample of working couples. For this purpose we use the 21 first waves of the German Socio-Economic Panel (GSEOP). We adapt to system GMM estimation the estimator presented in Semykina and Wooldridge (2005) to account for selection bias in the presence of endogenous regressors. Our results indicate that marriage increases women's specialization in home-based activities and that marriage decreases women's leisure. These effects are robust across specifications.

JEL Classification: J12, J22, C33, D13

Keywords: marriage, household allocation, domestic production, labor supply, panel data

Corresponding author:

Nicolas Moreau

Gremaq

Université des Sciences Sociales de Toulouse

Manufacture des Tabacs

Aile J-J Laffont

21 Allée de Brienne

31000 Toulouse

France

E-mail: nicolas.moreau@univ-tlse1.fr

\footnotetext{
* We thank Denis Beninger, Hélène Couprie, François Laisney and Stephan Thomsen for useful comments and suggestions. El Lahga thanks partial financial support provided by the Centre for European Economic Research (ZEW) in Mannheim where parts of this paper were written. The usual disclaimer applies.
} 


\section{Introduction}

Living arrangements have undergone considerable change in recent decades. In most Western countries marriage is no longer the exclusive context of family formation. In the United States (US) for instance, the number of unmarried couples nearly doubled in the 1990s, from 3.2 million couples in 1990 to 5.5 million couples in 2000 (source: U.S. Census Bureau). Le Goff (2002) reports that in the case of French women born between 1944 and 1948, 22 percent started their first union as a cohabiting union. For the cohort 1964-1968, this applies to 81 percent. In the former Federal Republic of Germany, about 38.3 percent of the women born between 1954 and 1958 started their first union outside of a formal marriage. The figure increases to 67.9 percent for the cohort $1964-1968$ (Le Goff, 2002). These demographic trends challenge microeconomic literature in which couples living in consensual unions are implicitly assumed to act identically as married couples.

A closer look at the literature reveals, however, growing evidence of the link between marital status and household behavior with respect to many outcomes. Using data from the US consumer expenditure survey, DeLeire and Kalil (2005) find that cohabitingparent families spend a greater amount on alcohol and tobacco, and a smaller amount on education and health care than married-parent families. Cohen (2002), Mamun (2004) and Stratton (2002) examine the wage differential for married and cohabiting men. Higher wage is observed for married men. McConocha et al. (1993) compare financial decisions between cohabiting, remarried and married couples. More recently, Rangel (2006) uses a sample of married Brazilian couples as a control group to identify the effect of extending alimony rights to cohabitants on adults' time allocation and investments in human capital of children. There is also evidence, based on US cross section data, that married couples exhibit a more 'traditional' division of domestic and market work than cohabitants (South and Spitze 1994, Stratton, 2005). ${ }^{1}$

\footnotetext{
${ }^{1}$ Waite (1995) offers a survey of the effects of marriage and cohabitation on health, mortality, children's well-being, assets and labor.
} 
The purpose of this paper is to evaluate whether the shift from cohabitation to marriage is associated with a significant change in household market and non-market labor supply. More specifically, we use a long German panel data (GSOEP) to test whether the transition from cohabitation to marriage reinforces the degree of specialization among couples. We estimate a model that relates married life to the female-to-male domestic and market work hours log ratios. Other regressors of the log ratios are the female relative earnings, the number of children and the duration of conjugal life. We account for selection bias in the presence of endogenous regressors following the procedure advocated in Semykina and Wooldridge (2005) that we adapt to system GMM estimation.

Our results suggest that marriage increases women's specialization in home-based activities. Important to note, marriage leads to a fall in women's leisure, particularly for couples with pre-school children. The results also exhibit a fall in married men's leisure coming from either a rise in market hours or an increase in domestic hours depending on the estimation.

The paper is structured as follows. Section 2 exposes the theoretical underpinning for the effects of marriage and cohabitation on market and non-market labor supply. Section 3 discusses the empirical specifications. Section 4 exposes the econometric issues. The data are described in Section 5. The results are presented in Section 6, and Section 7 concludes.

\section{Theoretical background}

The economic motivations which lie behind the existence of the household have been extensively discussed in the literature. At least since Becker (1973), it has been commonly argued that households exist because they allow household members to concentrate efficiently on activities in which each has a relative advantage. One partner can specialize in non-market, household activities while the other specializes in market work. The distinction between legal marriage and consensual union is not formally stated and "spouses" 
usually refers to two individuals sharing the same household. However, several arguments exist in the economic literature to predict that cohabitants specialize less than married couples.

First, cohabitants are often seen as playing non-cooperatively (Nordblom, 2004 and references therein). Cohabitations are usually shorter lived than marriages (Brien et al., 2006; Bumpass and Sweet, 1995) and there is consensus to admit that cooperation is more likely to occur in stable couples committed in a long term relationship. Stratton (2005) also puts forward the hypothesis that specialization is closely related to perceived household stability. Using US data, she presents some empirical evidence that the degree of specialization is greater within married couples compared to cohabitants. In contrast to cooperative settings, efficient specialization is less likely for couples playing strategically. For instance, Lundberg (2002) considers a bargaining model of intrahousehold allocation in a multi-period setting with limited commitment. Members are unable to make credible promises regarding future behavior. ${ }^{2}$ Inefficient levels of specialization and underprovision of household public good are likely outcomes. Basu (2006) specifies a bargaining model with an endogenous balance of power between partners and no intertemporal commitment. He shows that strategic considerations can lead to inefficient outcomes.

Second, consensual unions offer less legal protection than marriage. Married spouses are often obliged to care for each other and spousal maintenance is anticipated after divorce. Cohabitation provides individuals with less risk-sharing opportunities than marriage that may prevent individuals from specializing in home-based activities and household production skills. Cohabitants are thus less likely to specialize in household specific human capital. In this vein, Nordlom (2004) considers a model where married couples have legal restrictions on their relationship that force them to act cooperatively, while cohabitants with limited commitment act non-cooperatively. This makes precautionary savings greater for cohabitants than for married couples. ${ }^{3}$ In Germany, the article 6 GG of the Constitution obliges the state to promote the institutions of marriage and the fam-

\footnotetext{
${ }^{2}$ See also Wells and Maher (1998).

${ }^{3}$ Kotlikoff and Spivak (1981) and Anderberg (2003) also study risk sharing between spouses.
} 
ily through its legislation and to prevent any situation which could disadvantage these institutions (Stintzing, 1999). One spouse is obliged to support the other before the latter is entitled to subsidies from the state and this support is tax-deductible. This is not the case for cohabitants. In addition, the economic consequences of partnership dissolution are different for married couples and cohabiting couples. The German Constitution does not impose maintenance payments after non-marital separation. However, child support payment is anticipated. In 1994, suggestions to extend the protection of marriage to any form of long-term cohabitation were not passed in Parliament.

Finally, income tax distorts the allocation of time between married and cohabiting couples whenever they are subjected to different income tax schedules. In Germany, married couples can opt for the splitting system. Spouses' income is aggregated and halved, and the tax schedule is applied to this tax base. Married couples thus profit from a more favorable taxation in the case of an asymmetric earnings situation between the spouses (Gustafsson, 1992). As a result, tax saving is maximized for one earner household, or if partners combine full-time/part-time employment. From a theoretical perspective, Wrede (2003) analyzes among others things, the effect of joint taxation on specialization. Under the assumption that partners allocate their time efficiently between market and non-market activities through a Nash bargaining process, he shows that family members specialize more in reaction to joint taxation. Most importantly, only married couples can opt for the splitting system in Germany, while cohabitants face individual taxation. To the extent that it implies higher marginal tax rates on first earner and lower marginal tax rates on secondary earner, cohabitants have fewer incentives for specialization.

\section{$3 \quad$ Empirical Specifications}

We consider a household $i$ consisting of a female $(f)$ and a male $(m)$, that makes decisions about market work, non-market work, marital status and consumption. Let Married be a dummy variable denoting the marital status of the couple, with Married $=1$ if married 
and 0 otherwise. The two partners can choose to live under consensual union or legal marriage. Each partner $p(p=m, f)$ offers $l^{p}>0$ hours on the labor market at wage rate $w^{p}$ and spends $h^{p}>0$ hours in domestic work. Following Pollak and Wachter (1975) and Kooreman and Kapteyn (1987), we model the demand for consumption and the allocation of time by assuming that households or individuals maximize a utility function with goods and time spent on market and non-market activities as arguments. The allocation of time among market and non-market activities is thus expressed as a function of good prices, wage rates and non-labor income.

There are several ways of taking into account marital status in the utility function. In Couprie (2007), Gray (1997) and Lundberg and Rose (2002), to name a few, marital status is a predetermined variable. Current shocks on labor supply do not influence current marital status. The utility function at time $t$ is a function of current marital status but is maximized with respect to consumption goods and leisure only. Alternatively, marital status can be seen as a preference parameter that may vary over time. Couples may move from cohabitation to marriage and this change is likely to modify the allocation of time among market and non-market activities but marital status is not a choice variable per se.

However, it could be that marital status and the allocation of time are interrelated choices. Van der Klaaw (1996) explicitly studies their interdependence. In a life-cycle setting, the interaction between female labor force participation (not hours) and marital decision (married or single) is examined. Participation and marital status are the choice variables over which the utility function is maximized. Brien et al. (2006) estimate a model of non-marital cohabitation, marriage and divorce. They examine union formation and dissolution in the presence of uncertain match quality. They do not consider labor supply issues. Brien et al. (1999) focus on the interrelationship of cohabitation, marriage and childbearing while Lillard et al. (1995) analyze premarital cohabitation and the stability of later marriages.

In this paper, we estimate models with marriage assumed predetermined and models 
with endogenous marriage. We do not specify a structural model for the interaction between marital status and time use. We only instrument this variable in the market and non-market hours equations.

Also, we ignore the issue of union formation and dissolution. Our estimates may then suffer from selection bias but this problem is general to the labor supply literature. The analysis is usually done conditionally on household formation. We follow the bulk of the literature on this matter. ${ }^{4}$ Our results must be interpreted conditionally on couple formation.

Finally, conditioning the analysis on couples with strictly positive labor supplies also raises the problem of selectivity bias. Our estimation method tests and corrects for it.

We now present our base model. To analyze the extent of specialization within households, we specify a two-equation system that relates marriage, relative earnings and a set of preference factors to the female-to-male domestic and market work hours log ratios.

\subsection{The domestic and market work hours (log) ratios}

The base specification is:

$$
\begin{aligned}
& \ln \left(r_{i t}^{1}\right)=\alpha_{1} \text { Married }_{i t}+\beta_{1} \ln \left(\frac{w^{f}}{w^{m}}\right)+\gamma_{1} Y_{i t}+\delta_{1}^{\prime} Z_{i t}+\varepsilon_{i t}^{1} \\
& \ln \left(r_{i t}^{2}\right)=\alpha_{2} \text { Married }_{i t}+\beta_{2} \ln \left(\frac{w^{f}}{w^{m}}\right)+\gamma_{2} Y_{i t}+\delta_{2}^{\prime} Z_{i t}+\varepsilon_{i t}^{2},
\end{aligned}
$$

where $r^{1}=\frac{h^{f}}{h^{m}}$ is the female-to-male domestic work hours ratio, $r^{2}=\frac{l^{f}}{l^{m}}$ the female-tomale market work hours ratio, $Y$ is the household non-labor income, $Z$ is a vector of household characteristics including the constant term, $\varepsilon$ is a conformable error term, and $\alpha, \beta, \gamma$ and $\delta$ are the parameters to be estimated. The subscript $i$ indicates household and $t$ indicates time. This specification was already used in a unitary framework (Kiker and Ng, 1990) as well as in a collective setting (Browning and Gørtz, 2006). ${ }^{5}$

\footnotetext{
${ }^{4}$ See Blundell et al. (1998), Chiappori et al. (2002), and Pencavel (2006) among others.

${ }^{5}$ In the unitary framework, it is assumed that households, irrespective of the number of household members, behave as single decision makers. The collective setting introduced by Chiappori (1988) and
} 
Now we turn to the expected signs of the variables included in our empirical specification. As pointed out above, we expect a negative impact of marriage on women's relative hours on paid work $\left(r^{2}\right)$ and a positive effect on women's relative hours on unpaid work $\left(r^{1}\right)$. The overall effect on female relative leisure is undetermined a priori. Relative earnings $\left(\frac{w^{f}}{w^{m}}\right)$ are expected to be positively related to $r^{1}$ and negatively to $r^{2}$. Again, the overall effect on relative leisure is undetermined. Non-labor income has a positive effect on partners' leisure (if leisure is a normal good) but its impact on $r^{1}$ and $r^{2}$ is ambiguous.

We expect the specialization in home-based activities to increase with the duration of the relationship. To capture this effect we include a series of dummy variables Dur2, Dur3, Dur4 and Dur5 indicating the relationship duration in number of years. ${ }^{6}$ Also, the number and age of children are likely to influence the extent of specialization within the family. In line with the effect of children on female labor supply documented in the literature, we expect children to have a positive incidence on $r^{1}$ and a negative impact on $r^{2}$. We include the number of children under five and the number of children older than four in our specification.

One might argue that time allocation within the household is sensitive to generational effects. More precisely, younger cohorts may exhibit a more equal division of domestic work and paid labor. To test this hypothesis we include three cohort dummies in our model. Other factors such as nationality, regional disparities and religion may influence the intrafamily allocation of time. The dummy variable German00 is defined as 1 for non-German couples and 0 otherwise, German10 takes on the value 1 for couples with a German male partner and a non-German female partner whereas German01=1 for couples with a non-German male partner and a German female partner. Our control group is German couples. Included regions of residence are the southern and middle Apps and Rees (1988) takes into account several decision makers and the bargaining process. See also the
seminal paper of McElroy and Horney (1981) for a Nash-bargaining model applied to household behavior.
${ }^{6}$ Dur $2=\mathbf{1}[5 \leqslant$ duration $<10]$, Dur $3=\mathbf{1}[10 \leqslant$ duration $<15]$, Dur $4=\mathbf{1}[15 \leqslant$ duration $<20]$ and
Dur $5=\mathbf{1}$ [duration $\geqslant 20]$. 
states of West Germany, Baden-Württenberg, Rheinland Pfalz, Saarland and Bavaria. In contrast to the Protestant northern states, these regions include a majority of Catholics. ${ }^{7}$

\subsection{Alternative formulations}

We also focus on the effect of marriage on the level of market and non-market labor supply. We first consider a two-equation system that relates marital status, the female wage and the female unearned income (household non-labor income together with male labor earnings) to the female non-market and market labor supply. This setting is consistent with the theoretical models that assume the male allocation of time to be rigid. Actually, as exposed in Section 5, German men exhibit little variation in their number of domestic and market hours. ${ }^{8}$ This alternative specification is:

$$
\begin{aligned}
l_{i t}^{f} & =\alpha_{1} \text { Married }_{i t}+\beta_{1} \log \left(w_{i t}^{f}\right)+\gamma_{1} Y_{i t}^{f}+\delta_{1}^{\prime} Z_{i t}+\varepsilon_{i t}^{1} \\
h_{i t}^{f} & =\alpha_{2} \text { Married }_{i t}+\beta_{2} \log \left(w_{i t}^{f}\right)+\gamma_{2} Y_{i t}^{f}+\delta_{2}^{\prime} Z_{i t}+\varepsilon_{i t}^{2},
\end{aligned}
$$

where $Y^{f}$ is the female unearned income. Other variables are the same as before. The female wage is expected to have a positive effect on market hours and a negative effect on domestic hours. The female unearned income is expected to reduce women's hours in paid work.

Although men's labor supply is more concentrated than women's, there is some variation in the male allocation of time. We then specify a four-equation model where the male market and non-market labor supply are supposed to be flexible. Formally, we estimate

\footnotetext{
${ }^{7}$ Religious preferences are asked in the GSOEP but contain a lot of missing values.

${ }^{8}$ Blundell et al. (2005), Donni (2007) and Donni and Moreau (2007) deal with the rigidity of the man's behavior in a collective framework.
} 
the following system:

$$
\begin{aligned}
l_{i t}^{f} & =\alpha_{1} \text { Married }_{i t}+\beta_{1} \log \left(w_{i t}^{f}\right)+\eta_{1} \log \left(w_{i t}^{m}\right)+\gamma_{1} Y_{i t}+\delta_{1}^{\prime} Z_{i t}+\varepsilon_{i t}^{1} \\
h_{i t}^{f} & =\alpha_{2} \text { Married }_{i t}+\beta_{2} \log \left(w_{i t}^{f}\right)+\eta_{2} \log \left(w_{i t}^{m}\right)+\gamma_{2} Y_{i t}+\delta_{2}^{\prime} Z_{i t}+\varepsilon_{i t}^{2} \\
l_{i t}^{m} & =\alpha_{3} \text { Married }_{i t}+\beta_{3} \log \left(w_{i t}^{f}\right)+\eta_{3} \log \left(w_{i t}^{m}\right)+\gamma_{3} Y_{i t}+\delta_{3}^{\prime} Z_{i t}+\varepsilon_{i t}^{3} \\
h_{i t}^{m} & =\alpha_{4} \text { Married }_{i t}+\beta_{4} \log \left(w_{i t}^{f}\right)+\eta_{4} \log \left(w_{i t}^{m}\right)+\gamma_{4} Y_{i t}+\delta_{4}^{\prime} Z_{i t}+\varepsilon_{i t}^{4},
\end{aligned}
$$

where the covariates are the same as those of the base specification.

\section{Econometric issues}

In this section we discuss econometric issues that arise with our specification and we present our estimation method. We draw heavily upon Semykina and Wooldridge (2005). For the sake of simplicity, we consider one equation of interest to be estimated. All results can be easily generalized to a system of equations. A formal derivation is in Appendix A. We have:

$$
y_{i t}=x_{i t} \beta+\varepsilon_{i t},
$$

where $x_{i t}$ is a $1 \times K$ vector of explanatory variables, $\beta$ is a $K \times 1$ vector of parameters to be estimated, and $\varepsilon_{i t}$ is the error term.

First, we control for household-specific fixed effects $c_{i}$, which captures all unobserved household-specific heterogeneity in the labor supply that remains constant over time. The error term is then expressed as $\varepsilon_{i t}=c_{i}+u_{i t}$, where $u_{i t}$ are the idiosyncratic errors.

We allow for arbitrary correlation between the unobserved effect and the explanatory variables. In addition, we allow some elements of $x_{i t}$ to be endogenous (that is, correlated with the idiosyncratic error, $\left.u_{i t}\right)$. Let $z_{i t}$ a $1 \times L(L \geq K)$ vector of instruments which are strictly exogenous conditional on $c_{i}$. As previously mentioned, we focus our analysis on a sample of couples with strictly positive labor supply. Let $s_{i t}$ a binary selection rule that takes on the value 1 if the couple exhibits strictly positive market and non-market 
labor supply at period $t$, and 0 otherwise. Whether $s_{i t}$ equals 1 or $0, x_{i t}$ and $z_{i t}$ are always observed.

Semykina and Wooldridge (2005) -SW hereafter - show that applying the usual fixed effect two-stage least squares (FE-2SLS) estimator to the selected sample yields consistent estimates if $s_{i t}$ is completely random - technically $s_{i t}$ is independent of $\left(u_{i t}, z_{i t}, c_{i}\right)$ in all periods - or if $s_{i t}$ is a deterministic function of $\left(z_{i}, c_{i}\right)$, where $z_{i}=\left(z_{i 1}, \ldots, z_{i T}\right)$. Thus, in order to obtain consistent estimates one should carry out a formal test for sample selection and apply a correction method if necessary.

In what follows, we briefly sketch the procedure proposed by SW for linear fixed effects models. ${ }^{9}$ The selection indicator $s_{i t}$ is generated by means of a latent variable $s_{i t}^{*}$ such that:

$$
s_{i t}=\mathbf{1}\left[s_{i t}^{*}>0\right]=\mathbf{1}\left[z_{i t} \delta+a_{i}+u_{i t}>0\right],
$$

where 1[.] is the indicator function, $a_{i}$ is an unobserved effect and $u_{i t}$ is an error term defined such that $u_{i t} \mid z_{i}, e_{i} \sim N(0,1)$, so that $s_{i t}$ follows an unobserved effect probit model. To allow $a_{i}$ to be correlated with $z_{i}$, they specify, following Mundlak (1978),

$$
a_{i}=\eta+\xi \bar{z}_{i}+f_{i}
$$

where $\bar{z}_{i}$ is a vector of individual exogenous variables averaged across periods of time and $f_{i} \mid z_{i}$ has a zero mean normal distribution. Hence, the selection indicator $s_{i t}$ is rewritten as:

$$
s_{i t}=\mathbf{1}\left[\eta+z_{i t} \delta+\xi \bar{z}_{i}+v_{i t}>0\right]
$$

where $v_{i t}=\left(f_{i}+u_{i t}\right)$ has a zero mean normal distribution.

Now, suppose that $\left(\varepsilon_{i t}, v_{i}\right)$ is independent of $\left(z_{i}, c_{i}\right)$, where $v_{i}=\left(v_{i 1}, \ldots, v_{i T}\right)^{\prime}$, and $\left(\varepsilon_{i t}, v_{i t}\right)$ is independent of $\left(v_{i 1}, \ldots, v_{i, t-1}, v_{i, t+1}, \ldots, v_{i T}\right)$. If $E\left(\varepsilon_{i t} \mid v_{i t}\right)$ is linear, then:

$$
E\left(\varepsilon_{i t} \mid z_{i}, c_{i}, s_{i}\right)=\rho E\left(v_{i t} \mid z_{i}, c_{i}, s_{i}\right)=\rho E\left(v_{i t} \mid z_{i}, s_{i t}\right) .
$$

\footnotetext{
${ }^{9}$ Related papers are Gonzalez-Chapela (2004), Dustmann and Rochina-Barrachina (2000) and Kyriazidou (1997).
} 
Under the previous assumptions, we can write the primary equation (4) as:

$$
y_{i t}=x_{i t} \beta+c_{i}+\rho E\left(v_{i t} \mid z_{i}, s_{i t}\right)+e_{i t},
$$

where $e_{i t}$ is an idiosyncratic error term verifying $E\left(e_{i t} \mid z_{i}, c_{i}, s_{i}\right)=0$ by construction.

As noted above, the FE-2SLS yields a consistent estimation of the parameters of interest if the expectation given by (7) is 0 . Then, an immediate test for sample selection bias is obtained by testing $\mathbf{H}_{\mathbf{0}}: \rho=0$ in (8), which can be estimated by FE-2SLS. For the selected sample (that is, $\left.s_{i t}=1\right)$ we need only $E\left(v_{i t} \mid z_{i}, s_{i t}=1\right)$ which can be obtained from the usual probit estimation:

$$
E\left(v_{i t} \mid z_{i}, s_{i t}=1\right)=\lambda\left(\eta+z_{i t} \delta+\xi \bar{z}_{i}\right)
$$

where $\lambda($.$) denotes the inverse Mill's ratio. Let \widehat{\lambda}_{i t}$ its consistent estimate. To test for selection one simply has to estimate $P\left(s_{i t}=1 \mid z_{i}\right)=\Phi\left(\eta+z_{i t} \delta+\xi \bar{z}_{i}\right)$ with a reduced-form probit at each period $t$, to plug $\widehat{\lambda}_{i t}$ into the primary equation, to estimate the augmented primary equation by FE-2SLS and to test for $\mathbf{H}_{\mathbf{0}}: \rho=0$ with a simple $t$-statistic. To add more flexibility to the model, it is possible to interact $\widehat{\lambda}_{i t}$ with time dummies to allow the coefficient $\rho$ to be different across $t$. In this case, a Wald statistic is used to test the joint significance of the $T$ coefficients $\rho_{t}$. In our empirical specification, we use a FE-GMM estimator instead of the FE-2SLS and allow for different $\rho_{t}$.

SW offer a correction procedure for the sample selection problem when the null is rejected. It amounts to estimating equation (8) by Pooled 2SLS using a decomposition of the household-specific effect $c_{i}$ that follows Mundlak (1978). Under the previous assumptions about the selection rule and the unobserved effects, the primary equation of interest (4) can be rewritten as:

$$
y_{i t}=\alpha+x_{i t} \beta+\bar{z}_{i} \xi+\gamma_{t} E\left(v_{i t} \mid z_{i}, s_{i t}\right)+e_{i t}
$$

SW show that applying the Pooled 2SLS estimator to (10), after replacing $E\left(v_{i t} \mid z_{i}, s_{i t}\right)$ by the estimated inverse Mill's ratio $\widehat{\lambda}_{i t}$ yields a consistent estimator of the parameters. 
We adapt to system estimation the procedure presented in SW and propose a more efficient GMM estimator (Pooled GMM hereafter). Its derivation and the computation of the asymptotic variance estimator that accounts for the effect of using estimated rather than actual values for $\lambda_{i t}$ are collected in Appendix A.

Now, we address the question of the endogeneity of the regressors and the choice of the instruments. It is likely that hourly earnings and household non-labor income are not independent of hours worked. Therefore, we have chosen to instrument the woman's wage rate, the man's wage rate and the household non-labor income. One might also argue that the effect of marriage on labor supply can not be distinguished from the effect of pre-school children on parental time use. Indeed, the presence of children is more frequent among married couples in comparison with cohabitants who may enter marriage to begin childbearing or to legitimate the birth of a child. Child dependency on their mothers (breastfeeding for example) coupled with the virtual absence of child-care facilities in West Germany for small children ${ }^{10}$ create a strong incentive for specialization in conjunction with motherhood. To limit the extent of this problem, we focus on observations with no children under two. We account for this potential endogenous selection rule in our estimation procedure but assume that older children can be regarded as strictly exogenous after conditioning on the unobserved effect. This approach is commonly used in the literature (for instance Lundberg and Rose, 2002). Moreover, given that we ignore the issue of union formation and dissolution, we also consider the duration of the relationship to be strictly exogenous once we condition on the unobserved effect. Marital status will be either exogenous or endogenous depending on the estimations.

The set of excluded instruments that do not appear in the labor supply equations consists of the following variables: male and female years of schooling and their squares, male and female age and their squares, product of partners' age and education, and time dummies. Our intuition is that these variables have an impact on the various sources

\footnotetext{
${ }^{10}$ In West Germany full-day child-care is rare (Deutsches Jugendinstitut, 2002). Approximately 5 percent of children under age three are enrolled in formal child-care. Among three-five years old, 74.6 percent are enrolled in kindergarten (Gornick and Meyers, 2003).
} 
of the household income. ${ }^{11}$ Therefore, there are 26 excluded instruments from the labor supply equations.

Finally, it is important to have at least one instrument that affects only the selection equation. Otherwise the parameters of the primary equation are identified through the nonlinearity in the inverse Mill's ratios which is unlikely. We use the female and male unemployment rates as exclusive regressors for the probit model.

\section{The data}

Our data is drawn from the first 21 waves of the German Socio-Economic Panel (GSOEP) for the years 1984-2004. We extract a sample of observations that correspond to couples living in the former Federal Republic of Germany who are between 25 and 55 years old, who have finished their education and are available for the labor market. Households where adults are retired or students are then excluded. We also exclude households where adults are self-employed. Excluded from the sample are also couples who gave incomplete or incoherent information. In all, these selection criteria lead us to a sample of 4,762 couples resulting in 28,167 observations. On average, a couple appears six times over the 21 years period. The minimum time period is two years and the maximum 21 years. Of the 4,762 couples in our sample, 3,796 (79.71 percent) are always married, 364 (7.64 percent) always cohabiting and 602 (12.65 percent) make the transition from a cohabiting to a married couple. The couples who always live in a consensual union are observed on a shorter number of periods. Their average time period is four years within our observation window.

Also, to estimate the labor supply systems (1), (2) and (3) conditional on fixed effects, we need at least two observations for the same couple. Therefore, the data we use for estimating these equations uses all couples without children under two who report, for both partners, a strictly positive amount of domestic work and market work in at least

\footnotetext{
${ }^{11}$ These are standard instruments in the literature. See for instance Chiappori et al. (2002) among others.
} 
two periods. This leaves us with 12,925 observations from 2,762 households.

\section{Measuring time use}

Time spent on non-market work is computed as the sum of hours spent on housework (washing, cooking and cleaning), childcare, gardening and repairs in a typical weekday. Not all domestic work time is covered by this variable as weekend non-market work is not included. ${ }^{12}$ However, we probably account for a larger set of activities than that used when the question is only about time spent on housework in a normal week.

We measure time spent in market work as the annual work hours on all jobs divided by 365 (and by 366 for leap years). It corresponds to an average number of hours worked per day. This way, market work and non-market work have the same unit of time.

\section{Measuring earnings}

Total labor earnings include wages and salary from all jobs including overtime and secondary jobs. The wage rate is the average hourly earnings defined by dividing total labor income over annual hours of work on all jobs. Non-labor income includes income from asset flows, rent, private transfers, public transfers, etc. All these income variables are in euros adjusted for inflation with the price index provided by the GSOEP. Non-labor income is in thousands of euros.

\section{Measuring marital status}

The couple's marital status is represented with the dummy variable Married that takes on a value of 1 if the partners are legally married at the time of the interview, and 0 if they are cohabiting. ${ }^{13}$

\section{Measuring duration of conjugal life}

Duration of conjugal life can be computed from an extra file that contains yearly information on marital status. The data include the beginning and the ending of each marital status spell in years of age.

\section{TABLE 1 HERE}

\footnotetext{
${ }^{12}$ Complete information on weekend domestic work is asked only with waves 10, 12, 14, 16, 18 and 20.

${ }^{13}$ The distinction between legal marriage and cohabitation is made in the original data file, not in the GSOEP cross-national equivalent file.
} 
Summary statistics of the whole sample that includes nonparticipation in the labor market and in the house are given in Table 1. Sample characteristics are classified by marital status. The average age for men is 41 years and 39 years for women. From the 28,167 observations, 34 percent are women that do not participate in the labor market and 13 percent are men that do not work in the house. Of the 4,762 females (males) in our sample, 47.84 (88.70) percent always participate in the labor market and 18.5 (1.83) percent never. Only 1.81 percent of the men never work in the house.

Women who live in a consensual union participate more in the labor market than married women. On average, cohabiting couples are younger, have fewer children and are shorter lived than married couples. These findings could illustrate the transitional status of cohabitation but could also result from the composition of our sample. Cohabitation is indeed increasing over time. ${ }^{14}$ The variables related to consensual unions are thus more likely to suffer from right censoring.

\section{TABLE 2 HERE}

Table 2 reports statistics on the sample of households with no children under two and with both partners working in the labor market and in the house. The reported sample characteristics are classified by the number of children in the household and by marital status. On average, women work more hours in the house than men but less in the labor market. The variability of hours is lower for men: from the 12, 925 observations, 77 (38) percent are men (women) that work at most three hours in the house per day and 75 (46) percent are men (women) that work between 35 and 45 hours per week in paid jobs.

The domestic workload increases with the number of children. Also, married women work more in the house than cohabiting women and less in the labor market. In all, the female share of "total" work (total work is market work together with domestic work) is slightly greater than 50 percent for married women and for couples with children. It seems that men do not fully compensate for the fewer hours of domestic work by working

\footnotetext{
${ }^{14}$ About 4.32 (9.19) percent of the households in our sample live in a consensual union in 1984 (2004). The highest proportion is observed for 1995 with 12.32 percent of cohabiting couples.
} 
more in the market when they have children. Finally, women have a lower wage rate than men.

\section{Results}

\subsection{The effects of marriage on the domestic work and market work hours $(\log )$ ratios}

Conditioning the sample on households with working partners (that is, $h^{f}>0, l^{f}>0$, $h^{m}>0$ and $\left.l^{m}>0\right)$ and no children under two years of age may induce a selectivity bias. To account for all these selection rules we estimate 21 reduced-form participation equations and include the 21 inverse Mill's ratios into the market and non-market work equations. The results show a significant effect of the unemployment rates. ${ }^{15}$ Hence the domestic work and the market work equations, which exclude the latter variables, are well identified.

\subsubsection{Estimates from the sample of couples with no children under two}

The estimates of the base model (1) with exogenous marriage and using the fixed effect estimator FE-GMM are shown in Table 3. To save space, the coefficients of the 21 inverse Mill's ratios added to test for selection bias are not presented. Instead, we report a Wald statistic that tests their overall significance.

\section{TABLE 3 HERE}

At the five percent level, there is statistically significant evidence of selection bias for the log ratio of domestic hours but not for the log ratio of market hours. These results seem contradictory as our selection rule affects mainly couples with women that do not work in the labor market. Consequently, we decide to correct for contemporaneous selection in

\footnotetext{
${ }^{15}$ To save space the 21 probits are not reported. Results are available upon request.
} 
the equation related to domestic work but also in the equation related to market work. ${ }^{16}$ For this purpose, we use the Pooled GMM estimator that models the unobserved effect as a linear combination of the time averages of the exogenous variables. In comparison with the preceding estimation, we add eight time-constant regressors to explain the log ratios. Their effect could not be identified with the FE-GMM estimator.

The results are shown in Table 4 . The 13 coefficients related to the time averages and the 21 inverse Mills ratios are not reported. We present two Wald statistics that test their joint significance.

\section{TABLE 4 HERE}

Columns 1 and 2 in Table 4 report the estimates when marriage is assumed to be exogenous. At the five percent level, the time averages used to model the unobserved effect are jointly significant for both equations. Like the estimates obtained with the FEGMM estimator, there is only evidence of sample selection for the log ratio of domestic hours. Also, the Sargan's test does not reject the validity of the instruments and the overidentifying restrictions. We now turn to the parameters of main interest.

The results indicate that marriage has a significant effect on both domestic and market work. When women are married, their domestic workload increases relative to men whereas the ratio of female-to-male market hours falls. All else being equal, married women are more likely to specialize in domestic work than cohabiting women.

Relative earnings have a negative effect on the ratio of non-market hours. A one percent rise in relative earnings leads to a 1.034 percent decrease in the ratio of nonmarket hours. Women with a high relative wage are less likely to specialize in domestic activities. On the contrary, relative earnings have a positive impact on the log ratio of market hours. The division of market work between partners is more equal for high female relative wages. Also, non-labor income has a significant and negative impact on the log

\footnotetext{
${ }^{16} \mathrm{We}$ also estimate the model that accounts for selection bias only for the female relative domestic workload. The estimates are very similar.
} 
ratio of unpaid hours. It could be that wealthy couples buy more market substitutes for home-based activities.

The presence of children in the household, especially of young children, raises women's domestic workload relative to men and decreases their share of market work. This is in accordance with the negative correlation between children and female market labor supply usually observed in empirical studies. Moreover, some regional disparities explain the division of domestic work between men and women. The female relative domestic workload is higher for households living in the southern states of West Germany. The ratio of female-to-male domestic hours is also higher for German born women living with a non-German partner.

We note that the duration of the relationship has a negative impact on the ratio of market hours. Longer durations lead to a fall in the female relative market workload whereas the results exhibit a cohort effect. Younger women are less likely to specialize in unpaid work than their elders.

\subsubsection{Testing exclusion restrictions}

We now consider whether education, age and unemployment rates (which appear in the selection equation) are valid exclusion restrictions. Including these variables in the log ratios equations does not have significant effects on the original parameters estimates and their coefficients are insignificant. The effect of the duration of conjugal life on the log ratio of market work remains when age is a regressor. The $t$-values for the coefficients of the female education (age) are below 1.40 (1.33) whereas the $t$-values for the male education (age) are below 1.17 (1.33). We hence maintain these exclusion restrictions. We also test for interaction terms between marital status and wages and between marital status and the duration of conjugal life. Whatever the sample used, none of them are significant. 


\subsubsection{Endogeneity of marriage}

Thus far, we have considered that being married or cohabiting can be regarded as exogenous after conditioning on the unobserved effect. However, it can be that time use (market versus non-market activities) and marital status (married versus cohabiting) are interdependent choices. If this is the case, marital status is endogenous. Columns 3 and 4 in Table 4 report the estimates when married life is instrumented. The duration of the relationship is used as a supplementary excluded instrument. ${ }^{17}$

The effects of marriage on the ratios of domestic work hours and market work hours are still significant when it is instrumented. However, the estimated coefficients of marriage exhibit a severe change in magnitude from that observed when this variable is assumed to be exogenous. It is possible that the effects of married life are seriously underestimated when marriage is supposedly exogenous. On the other hand, such large variations in the estimated coefficients of marriage can denote a problem of weak instruments. ${ }^{18}$ In such a case, and with no other relevant instruments for marriage, it may be better to just assume its exogeneity. Nevertheless, being married still raises the female relative domestic workload and decreases the female relative market workload, just as before. The effects of the other explanatory variables are in line with those reported when marriage are supposedly to be exogenous.

\subsubsection{Does marriage cause this outcome?}

If married couples exhibit systematic different characteristics than cohabitants then the observed effects of marriage may only reflect that we are estimating our model on two distinct populations. To check this assumption we estimate the model with a different

\footnotetext{
${ }^{17}$ We test for the endogeneity of the duration of conjugal life whether marital status is assumed to be exogenous or endogenous. In both cases we do not reject the null (that is, the exogeneity of the duration of conjugal life).

${ }^{18}$ We estimate the model with other instruments such as the female-to-male age and education ratios. It does not change the estimates. Also, as mentioned in Browning (1992), the usual practice of treating dummies as unbounded and continuous in the auxiliary equation may cause problems.
} 
marital status variable (Change hereafter) that takes on the value one for observations that correspond to married couples previously cohabiting. It is zero for couples that are either cohabiting or always married. This variable is for the permanent effect of the transition from cohabitation to marriage on time use. Interestingly, its effect on domestic and market work hours is significant and very similar to that in Table 4. The transition from cohabitation to married life, when assumed to be exogenous, increases the log ratio of domestic work hours by 0.150 and decreases the log ratio of market work hours by -0.099 (Table 13 in Appendix B reports the results). We interpret this result as evidence of no selection into marriage.

\subsubsection{Robustness checks: Estimates from the samples of couples with no children under five and no children under eleven}

As previously mentioned, it could be difficult to disentangle the observed effect of marriage on labor supply from the effect of children. To give more robustness to our results, we re-estimate the model on the sample of couples with no children under five and on the sample of couples with no children under eleven. This leaves us with 11,727 observations from 2,579 households if we include all observations with no children under five or with 8, 657 observations from 2,041 couples if we include all observations with no children under eleven.

\section{TABLE 5 HERE}

Columns (1) and (2) of Table 5 are the estimates with no children under five, and columns (3) and (4) are the estimates with no children under eleven. Marriage is assumed to be exogenous. On the whole, the coefficients of the sample with no children under eleven are less precisely estimated. As for couples with no children under two, the Sargan's tests does not reject the validity of the instruments and the overidentifying restrictions. For couples with no children under eleven, sample selection is not likely to be a problem in the non-market work equation but in the market labor supply equation. 
For couples with no children under five, relative earnings still have a significant and negative effect - though smaller in magnitude - on the ratio of non-market hours and a significant and positive impact on the ratio of market hours. The effect of relative earnings is insignificant for couples with no children under eleven. Also, whatever the children's age, non-labor income continues to have a significant and negative impact on the log ratio of domestic hours.

The marital status coefficients exhibit a substantial fall in magnitude when we move from couples with pre-school children to couples with no children under eleven. It suggests that the effect of marriage on the parental allocation of time is higher for couples with young children. It is also possible that the marital status coefficients grasp part of the effect of children on time use as married couples tend to have more children. However this may be, the effect of marriage is significant and has the expected sign. Married life increases women's specialization in home-based activities.

This effect remains when marriage is instrumented; though with a large variation in the point estimates (see Table 6). Finally, married life also increases women's specialization in domestic work when we only account for the effect of the transition from cohabitation to marriage. The rise in the log ratio of unpaid work hours is 0.113 and 0.087 , and the fall in the log ratio of paid work hours is -0.091 and -0.082 , for couples with no children under five and no children under eleven respectively. ${ }^{19}$

\section{TABLE 6 HERE}

\subsection{Alternative formulations: the effects of marriage on domes- tic work and market work hours}

In this section the two alternative specifications of the model are considered. Tables 7 and 9 report the estimates of the alternative model (2) where market work and domestic work are supposed to be rigid for men. Tables 10 and 12 report the estimates of the alternative

\footnotetext{
${ }^{19}$ Marriage is assumed to be exogenous. Detailed results are available upon request.
} 
model (3) where men's market work and non-market work hours are supposedly flexible. Two supplementary explanatory variables are the female age in the equations related to women and the male age in the equations related to men.

\subsubsection{The effects of marriage on women's domestic and market work hours}

To save space, only the Pooled GMM estimates are shown. We report estimates for the observations with no children under two, with no children under five and with no children under eleven, respectively.

Table 7 reports the results when marriage is assumed to be exogenous. At conventional levels, we do not reject the validity of the instruments and the overidentifying restrictions for the estimations with no children under five. For the model with no children under eleven, the null of overidentification is rejected at the ten percent level. Again, fewer parameters are statistically different from 0 when we consider only couples with no children under eleven. On the whole, the results are in accordance with those obtained for the base model. Also, there is evidence of selection in domestic hours as well as market hours.

Marriage has a positive effect on the female number of domestic hours and a negative effect on the female number of market hours. Interestingly, the former effect offsets the latter so that "pure" leisure falls for married women, especially for couples with pre-school children.

\section{TABLE 7 HERE}

For couples with no children under five, an increase in the female wage leads to a rise in the number of market hours and to a fall in the number of domestic hours. Wages are statistically insignificant for couples with no children under eleven. Own wage elasticities of market work and domestic work are shown in Table 8. The market work elasticities are significantly different from zero at the ten percent level for couples with no children under five. These are not intertemporal elasticities as we do not account for intertemporal budgeting in our model. However, the amplitude of the market work elasticities is in line 
with that found in other studies using German data. For example, Laisney et al. (1993) report median intertemporal wage elasticities that range from 0.46 to 0.60 depending on the estimation. The wage elasticity is 0.40 for West German couples in Steiner and Jacobebbinghaus (2003). For couples with no children under five, wages have a more significant effect on women's hours of domestic work than of market work. A similar pattern is found in Davies et al. (2000). Also, the number of domestic hours increases with the non-female income.

\section{TABLE 8 HERE}

The results show a strong effect of pre-school children and a significant effect of the duration of conjugal life on women's time use. Women that have been living with a partner for a certain period of time spend more hours on home-based activities and fewer hours on market activities than the others. This is consistent with Becker's notion of increasing relationship-specific capital.

Finally, Table 9 reports the estimates when married life is instrumented. The point estimates of marriage are very different to those in Table 7. For couples with no children under two (five), marriage now increases by 7.229 (6.852) the number of hours per day that women spend in home-based activities, which is unreliable. It is very likely that married life suffers from weak instruments. Moreover, none of the wage and non-female income parameters are different from zero. However, the qualitative impact of marriage on female labor supplies remains the same. Pure leisure decreases for married women. We now turn to the estimates of the second alternative specification.

\section{TABLE 9 HERE}

\subsubsection{The effects of marriage on female and male domestic and market work hours}

Table 10 reports the estimates when marriage is assumed to be exogenous. To save space, only the estimates on the base sample with no children under two are shown. We note that 
the parameters of the male equations have large standard errors. This lack of precision is explained by the little variation in the male allocation of time. For the estimation with no children under eleven, very few parameters are statistically different from zero and the validity of the instruments and the overidentifying restrictions is rejected.

\section{TABLE 10 HERE}

For couples with no children under two, most of the parameter estimates of the female equations are in line with those in Table 7 . The overall qualitative results remain the same. In particular, married life increases women's number of domestic hours and decreases their number of market hours such that the total effect is a fall in women's pure leisure. However for couples with no children under five, married life has no significant effect on women's domestic work and its impact on women's market work is significant at the ten percent level only. For men, there is evidence that married life significantly raises their market labor supply at conventional levels for the population of couples with no children under five.

\section{TABLE 11 HERE}

Own and cross wage elasticities are shown in Table 11. Women exhibit a wage elasticity of domestic work slightly lower than that of Table 8. Their cross wage elasticity of domestic work is significant and positive (for couples with no children under five). Again, domestic work is more elastic than market work for women. On the contrary, men's domestic labor supply is inelastic.

\section{TABLE 12 HERE}

Finally, we present in Table 12 the estimates with marriage being instrumented. The validity of the instruments and the overidentifying restrictions are accepted at the one percent level only. Once again, the instrumentation of marriage leads to a huge variation in the point estimates of this variable but the qualitative effect of marriage on women's 
allocation of time is the same. Married women spend more time on domestic work and fewer hours on market work. Also, it seems that marriage now has a significant and positive effect on male domestic work whereas its impact on male market work is not significant anymore.

\section{Conclusion}

In this paper, we have estimated the effects of the transition from cohabitation to marriage on household market and non-market labor supply using a German sample of working couples. Our results indicate that marriage raises women's specialization in domestic work with a greater impact on couples with preschool children. We find that specialization in unpaid work is less likely for women with a high market wage.

These findings are robust across specifications. Actually, marriage increases women's specialization in home-based activities whether we consider the female-to-male domestic and market work hours (log) ratios or women's market and non-market labor supply or men's and women's market and non-market labor supply.

Interestingly, we find that married women enjoy less leisure than cohabiting women. Marriage decreases women's market work and increases their domestic work so that the overall effect is a fall in their leisure. We also found evidence that married men enjoy less leisure than cohabiting men but the effect of marriage on men's labor supply is less clear cut due to little variation in the male allocation of time.

Finally, the estimated coefficients of marriage change drastically when marital status is assumed to be endogenous but the qualitative results remain the same. Marriage still increases women's specialization in unpaid work. It could also be that marriage influences

the decision to participate in the labor market. In this case, the idea is to estimate structural participation equations with marital status as an explanatory variable. This is a topic of future work. 
Table 1: Descriptive Statistics of the Whole Sample

\begin{tabular}{lcccc}
\hline \hline & \multirow{2}{*}{ Total } & \multicolumn{3}{c}{ Marital status } \\
& & AM & CM & AC \\
\hline Age $(f)$ & 38.70 & 39.69 & 33.88 & 35.91 \\
& $(7.58)$ & $(7.39)$ & $(6.43)$ & $(7.85)$ \\
Age $(m)$ & 41.21 & 42.33 & 35.98 & 37.35 \\
& $(7.77)$ & $(7.53)$ & $(6.53)$ & $(7.74)$ \\
Market work participation $(f)$ & 0.66 & 0.62 & 0.80 & 0.88 \\
& $(0.47)$ & $(0.48)$ & $(0.40)$ & $(0.33)$ \\
Market work participation $(m)$ & 0.95 & 0.95 & 0.96 & 0.92 \\
& $(0.22)$ & $(0.22)$ & $(0.20)$ & $(0.27)$ \\
Non-market work participation $(f)$ & 0.99 & 0.99 & 0.99 & 0.98 \\
& $(0.08)$ & $(0.07)$ & $(0.11)$ & $(0.14)$ \\
Non-market work participation $(m)$ & 0.87 & 0.87 & 0.90 & 0.85 \\
& $(0.34)$ & $(0.34)$ & $(0.30)$ & $(0.35)$ \\
Number of children $(f)$ & 1.37 & 1.54 & 0.72 & 0.44 \\
& $(1.16)$ & $(1.15)$ & $(0.91)$ & $(0.77)$ \\
Education level $(f)$ & 10.99 & 10.74 & 12.04 & 12.27 \\
& $(2.41)$ & $(2.33)$ & $(2.35)$ & $(2.67)$ \\
Education level $(m)$ & 11.44 & 11.27 & 12.26 & 12.00 \\
& $(2.56)$ & $(2.51)$ & $(2.68)$ & $(2.61)$ \\
Duration of conjugal life & 16.98 & 18.96 & 10.26 & 7.44 \\
& $(9.03)$ & $(8.61)$ & $(5.63)$ & $(5.79)$ \\
Number of observations & 28,167 & 22,882 & 3,891 & 1,394 \\
\hline
\end{tabular}

Notes: Sample standard deviations are in parentheses below sample means. "AM" refers to couples that are always married, "CM" to couples that transit from consensual union to marriage and "AC" to couples that are always cohabiting. The duration of conjugal life is the maximum duration observed per couple. Its average is computed over the 4,762 couples, not over the 28,167 observations. 
Table 2: Descriptive Statistics of the Second Step Sample

\begin{tabular}{lcccccccc}
\hline \hline & Total & \multicolumn{3}{c}{ Number of children } & \multicolumn{3}{c}{ Marital status } \\
\hline & & 0 & 1 & 2 & 3 & AM & CM & AC \\
Age $(f)$ & 39.15 & 37.02 & 40.19 & 40.13 & 40.53 & 40.52 & 34.27 & 35.53 \\
& $(7.39)$ & $(8.84)$ & $(6.97)$ & $(5.75)$ & $(5.38)$ & $(6.96)$ & $(6.62)$ & $(7.66)$ \\
Age $(m)$ & 41.70 & 39.27 & 42.69 & 42.87 & 43.87 & 43.24 & 36.45 & 37.16 \\
& $(7.56)$ & $(8.76)$ & $(7.16)$ & $(6.01)$ & $(5.75)$ & $(7.04)$ & $(6.79)$ & $(7.40)$ \\
& & & & & & & & \\
Domestic & 5.21 & 2.67 & 5.91 & 6.84 & 7.24 & 5.57 & 4.44 & 2.91 \\
hours $(f)$ & $(3.41)$ & $(1.63)$ & $(3.16)$ & $(3.50)$ & $(3.28)$ & $(3.31)$ & $(3.73)$ & $(2.46)$ \\
Domestic & 2.69 & 2.02 & 2.94 & 3.07 & 3.21 & 2.77 & 2.58 & 2.08 \\
hours $(m)$ & $(1.85)$ & $(1.24)$ & $(1.99)$ & $(1.96)$ & $(2.17)$ & $(1.87)$ & $(1.81)$ & $(1.52)$ \\
& & & & & & & & \\
Market & 4.31 & 5.29 & 4.03 & 3.66 & 3.62 & 4.15 & 4.73 & 5.22 \\
hours $(f)$ & $(1.65)$ & $(1.28)$ & $(1.56)$ & $(1.59)$ & $(1.61)$ & $(1.63)$ & $(1.63)$ & $(1.44)$ \\
Market & 5.93 & 5.95 & 5.92 & 5.93 & 5.93 & 5.93 & 5.94 & 5.98 \\
hours $(m)$ & $(1.11)$ & $(1.13)$ & $(1.08)$ & $(1.13)$ & $(1.13)$ & $(1.08)$ & $(1.19)$ & $(1.28)$ \\
& & & & & & & & \\
Wage rate $(f)$ & 11.27 & 12.13 & 11.22 & 10.54 & 10.55 & 11.06 & 11.91 & 12.16 \\
& $(4.55)$ & $(4.35)$ & $(4.57)$ & $(4.59)$ & $(4.61)$ & $(4.57)$ & $(4.38)$ & $(4.52)$ \\
Wage rate $(m)$ & 15.01 & 14.84 & 15.02 & 15.31 & 14.71 & 15.11 & 14.73 & 14.61 \\
& $(4.78)$ & $(4.79)$ & $(4.81)$ & $(4.74)$ & $(4.72)$ & $(4.76)$ & $(4.74)$ & $(5.11)$ \\
Share of & & & & & & & & \\
total work $(f)$ & $(0.07)$ & $(0.07)$ & $(0.07)$ & $(0.08)$ & $(0.07)$ & $(0.07)$ & $(0.08)$ & $(0.07)$ \\
Number of & 12,925 & 4,325 & 3,821 & 3,642 & 1,137 & 9,914 & 2,184 & 827 \\
observations & & & & & & & & \\
\hline & & & & & & & &
\end{tabular}

Notes: Sample standard deviations are in parentheses below sample means. "AM" refers to couples that are always married, "CM" to couples that transit from consensual union to marriage and "AC" to couples that are always cohabiting. 
Table 3: The effects of married life on the female-to-male domestic and market work hours (log) ratios - FE-GMM estimates

\begin{tabular}{lll}
\hline \hline & $r^{1}=\frac{h^{f}}{h^{m}}$ & $r^{2}=\frac{l^{f}}{l^{m}}$ \\
\hline Married & 0.112 & -0.084 \\
& $(0.055)$ & $(0.032)$ \\
Log wage ratio & -1.74 & 1.008 \\
& $(0.432)$ & $(0.291)$ \\
Non-labor income & -0.002 & -0.000 \\
& $(0.009)$ & $(0.006)$ \\
Dur2 & 0.019 & -0.072 \\
& $(0.039)$ & $(0.025)$ \\
Dur3 & 0.03 & -0.087 \\
& $(0.06)$ & $(0.039)$ \\
Dur4 & 0.048 & -0.116 \\
& $(0.07)$ & $(0.045)$ \\
Dur5 & 0.079 & -0.106 \\
& $(0.078)$ & $(0.05)$ \\
Children under 5 & 0.102 & -0.223 \\
& $(0.064)$ & $(0.044)$ \\
Children 5+ & 0.069 & -0.079 \\
& $(0.029)$ & $(0.019)$ \\
Wald test $\hat{\lambda}_{i t}$ & 35.337 & 9.46 \\
P-value & 0.026 & 0.985 \\
Sargan's test & \multicolumn{2}{c}{31.896} \\
P-Value & \multicolumn{2}{c}{0.964} \\
\hline \hline o: Asymptotic standard errors are in parentheses.
\end{tabular}


Table 4: The effects of married life on the female-to-male domestic and market work hours (log) ratios - Pooled GMM estimates

\begin{tabular}{|c|c|c|c|c|}
\hline & \multicolumn{2}{|c|}{ Marriage is exogenous } & \multicolumn{2}{|c|}{ Marriage is endogenous } \\
\hline & $r^{1}=\frac{h^{f}}{h^{m}}$ & $r^{2}=\frac{l^{f}}{l^{m}}$ & $r^{1}=\frac{h^{f}}{h^{m}}$ & $r^{2}=\frac{l^{f}}{l^{m}}$ \\
\hline \multirow[t]{2}{*}{ Married } & 0.153 & -0.09 & 0.375 & -0.435 \\
\hline & $(0.049)$ & $(0.030)$ & $(0.184)$ & $(0.115)$ \\
\hline \multirow[t]{2}{*}{ Log Wage ratio } & -1.034 & 0.726 & -1.067 & 0.631 \\
\hline & $(0.342)$ & $(0.220)$ & $(0.38)$ & $(0.239)$ \\
\hline \multirow[t]{2}{*}{ Non-labor income } & -0.020 & 0.006 & -0.034 & 0.012 \\
\hline & $(0.010)$ & $(0.006)$ & $(0.013)$ & $(0.007)$ \\
\hline \multirow{2}{*}{ Dur2 } & -0.002 & -0.066 & & \\
\hline & $(0.033)$ & $(0.020)$ & & \\
\hline \multirow[t]{2}{*}{ Dur3 } & 0.012 & -0.078 & & \\
\hline & $(0.045)$ & $\begin{array}{l}(0.029) \\
-0.098\end{array}$ & & \\
\hline Dur4 & $\begin{array}{c}0.006 \\
(0.059)\end{array}$ & $\begin{array}{l}-0.098 \\
(0.038)\end{array}$ & & \\
\hline \multirow[t]{2}{*}{ Dur5 } & -0.035 & -0.064 & & \\
\hline & $(0.068)$ & $(0.043)$ & & \\
\hline \multirow[t]{2}{*}{ Children under 5} & 0.276 & -0.280 & 0.287 & -0.299 \\
\hline & $(0.049)$ & $(0.033)$ & $(0.053)$ & $(0.034)$ \\
\hline \multirow[t]{2}{*}{ Children 5+ } & 0.129 & -0.096 & 0.135 & -0.108 \\
\hline & $(0.024)$ & $(0.015)$ & $(0.027)$ & $(0.016)$ \\
\hline \multirow[t]{2}{*}{ Middle regions } & 0.072 & 0.009 & 0.08 & -0.004 \\
\hline & $(0.032)$ & $(0.022)$ & $(0.035)$ & $(0.023)$ \\
\hline \multirow{2}{*}{ Southern regions } & 0.087 & 0.002 & 0.097 & -0.003 \\
\hline & $(0.025)$ & $(0.017)$ & $(0.027)$ & $(0.017)$ \\
\hline \multirow[t]{2}{*}{ German00 } & 0.113 & 0.026 & 0.111 & 0.067 \\
\hline & $(0.089)$ & $(0.069)$ & $(0.097)$ & $(0.072)$ \\
\hline \multirow[t]{2}{*}{ German10 } & -0.010 & -0.037 & 0.006 & -0.042 \\
\hline & $(0.050)$ & $(0.040)$ & $(0.055)$ & $(0.044)$ \\
\hline \multirow[t]{2}{*}{ German01 } & 0.123 & -0.116 & 0.139 & -0.11 \\
\hline & $(0.058)$ & $(0.047)$ & $(0.061)$ & $(0.047)$ \\
\hline \multirow[t]{2}{*}{ Cohort 1931-45 } & 0.159 & -0.018 & 0.108 & 0.009 \\
\hline & $(0.064)$ & $(0.044)$ & $(0.062)$ & $(0.042)$ \\
\hline \multirow[t]{2}{*}{ Cohort 1946-55 } & 0.089 & 0.003 & 0.073 & 0.013 \\
\hline & $(0.036)$ & $(0.024)$ & $(0.037)$ & $(0.024)$ \\
\hline \multirow[t]{2}{*}{ Cohort 1966-79 } & -0.108 & 0.012 & -0.076 & -0.014 \\
\hline & $(0.039)$ & $(0.024)$ & $(0.043)$ & $(0.026)$ \\
\hline \multirow[t]{2}{*}{ Intercept } & 0.473 & 0.502 & 0.323 & 0.584 \\
\hline & $(0.370)$ & $(0.253)$ & $(0.411)$ & $(0.264)$ \\
\hline Wald test $\widehat{\lambda}_{i t}$ & 34.624 & 24.857 & 36.598 & 29.598 \\
\hline $\mathrm{P}$-value & 0.031 & 0.253 & 0.019 & 0.100 \\
\hline Wald test $\bar{z}_{i t}$ & 49.336 & 49.103 & 33.976 & 29.618 \\
\hline $\mathrm{P}$-value & 0.000 & 0.000 & 0.001 & 0.003 \\
\hline Sargan's test & & & & 13 \\
\hline P-Value & & & & \\
\hline
\end{tabular}

Note: Asymptotic standard errors are in parentheses. 
Table 5: Alternative samples: the effects of married life on the female-to-male domestic and market work hours (log) ratios - Pooled GMM estimates, marriage is exogenous

\begin{tabular}{|c|c|c|c|c|}
\hline & \multicolumn{2}{|c|}{ No children under five } & \multicolumn{2}{|c|}{ No children under eleven } \\
\hline \multirow{3}{*}{ Married } & $r^{1}=\frac{h^{f}}{h^{m}}$ & $r^{2}=\frac{l^{f}}{l^{m}}$ & $r^{1}=\frac{h^{f}}{h^{m}}$ & $r^{2}=\frac{l^{f}}{l^{m}}$ \\
\hline & $0.126^{h^{m}}$ & -0.099 & $0.094^{h^{m}}$ & -0.078 \\
\hline & $(0.049)$ & $(0.032)$ & $(0.047)$ & $(0.024)$ \\
\hline \multirow[t]{2}{*}{ Log wage ratio } & -0.893 & 0.757 & -0.090 & -0.125 \\
\hline & $(0.341)$ & $(0.227)$ & $(0.318)$ & $(0.198)$ \\
\hline \multirow{2}{*}{ Non-labor income } & -0.019 & 0.01 & -0.025 & 0.000 \\
\hline & $(0.011)$ & $(0.007)$ & $(0.013)$ & $(0.008)$ \\
\hline \multirow[t]{2}{*}{ Dur2 } & -0.016 & -0.057 & -0.071 & -0.005 \\
\hline & $(0.034)$ & $(0.022)$ & $(0.036)$ & $(0.02)$ \\
\hline \multirow[t]{2}{*}{ Dur3 } & 0.039 & -0.079 & -0.041 & -0.013 \\
\hline & $(0.046)$ & $(0.032)$ & $(0.046)$ & $(0.029)$ \\
\hline \multirow[t]{2}{*}{ Dur4 } & 0.012 & -0.080 & 0.102 & -0.158 \\
\hline & $(0.059)$ & $(0.041)$ & $(0.058)$ & $(0.04)$ \\
\hline \multirow[t]{2}{*}{ Dur5 } & -0.021 & -0.051 & 0.084 & -0.160 \\
\hline & $(0.07)$ & $(0.047)$ & $(0.072)$ & $(0.049)$ \\
\hline \multirow[t]{2}{*}{ Children 5+ } & 0.14 & -0.098 & 0.099 & -0.065 \\
\hline & $(0.023)$ & $(0.017)$ & $(0.022)$ & $(0.013)$ \\
\hline \multirow[t]{2}{*}{ Middle regions } & 0.087 & -0.002 & 0.103 & -0.019 \\
\hline & $(0.031)$ & $(0.022)$ & $(0.031)$ & $(0.026)$ \\
\hline \multirow[t]{2}{*}{ Southern regions } & 0.107 & -0.004 & 0.105 & 0.013 \\
\hline & $(0.025)$ & $(0.018)$ & $(0.026)$ & $(0.02)$ \\
\hline \multirow[t]{2}{*}{ German00 } & 0.122 & -0.010 & -0.061 & 0.157 \\
\hline & $(0.093)$ & $(0.074)$ & $(0.092)$ & $(0.087)$ \\
\hline \multirow[t]{2}{*}{ German10 } & 0.024 & -0.053 & -0.000 & 0.004 \\
\hline & $(0.048)$ & $(0.042)$ & $(0.053)$ & $(0.062)$ \\
\hline \multirow[t]{2}{*}{ German01 } & 0.11 & -0.128 & 0.017 & -0.081 \\
\hline & $(0.059)$ & $(0.05)$ & $(0.059)$ & $(0.051)$ \\
\hline \multirow{2}{*}{ Cohort 1931-45 } & 0.126 & -0.023 & 0.007 & 0.01 \\
\hline & $(0.064)$ & $(0.045)$ & $(0.066)$ & $(0.052)$ \\
\hline \multirow[t]{2}{*}{ Cohort 1946-55 } & 0.076 & -0.002 & 0.003 & 0.023 \\
\hline & $(0.035)$ & $(0.026)$ & $(0.038)$ & $(0.03)$ \\
\hline \multirow[t]{2}{*}{ Cohort 1966-79 } & -0.098 & 0.004 & -0.143 & 0.022 \\
\hline & $(0.041)$ & $(0.027)$ & $(0.046)$ & $(0.027)$ \\
\hline Intercept & 0.629 & 0.343 & 0.995 & -0.063 \\
\hline Wald test $\widehat{\lambda}_{i t}$ & 32629 & $\begin{array}{l}(0.204) \\
28.658\end{array}$ & $\begin{array}{l}(0.002) \\
19158\end{array}$ & $\begin{array}{l}(0.284) \\
34855\end{array}$ \\
\hline P-value & 0.050 & 0.122 & 0.575 & 0.029 \\
\hline Wald test $\bar{z}_{i t}$ & 29.214 & 29.168 & 29.643 & 27.188 \\
\hline $\mathrm{P}$-value & 0.002 & 0.002 & 0.002 & 0.004 \\
\hline Sargan's test & \multicolumn{2}{|c|}{41.692} & \multirow{2}{*}{\multicolumn{2}{|c|}{$\begin{array}{l}52.643 \\
0299\end{array}$}} \\
\hline P-Value & \multicolumn{2}{|c|}{0.728} & & \\
\hline
\end{tabular}


Table 6: Alternative samples: the effects of married life on the female-to-male domestic and market work hours $(\log )$ ratios - Pooled GMM estimates, marriage is endogenous

\begin{tabular}{lcccc}
\hline \hline & \multicolumn{2}{c}{ No children under five } & \multicolumn{2}{c}{ No children } \\
& $r^{1}=\frac{h^{f}}{h^{m}}$ & $r^{2}=\frac{l^{f}}{l^{m}}$ & $r^{1}=\frac{h^{f}}{h^{m}}$ & $r^{2}=\frac{l^{f}}{l^{m}}$ \\
\hline Married & 0.516 & -0.506 & 0.381 & -0.431 \\
& $(0.172)$ & $(0.113)$ & $(0.155)$ & $(0.096)$ \\
Log wage ratio & -0.767 & 0.625 & -0.254 & -0.105 \\
& $(0.357)$ & $(0.23)$ & $(0.327)$ & $(0.214)$ \\
Non-labor income & -0.041 & 0.02 & -0.038 & 0.006 \\
& $(0.014)$ & $(0.009)$ & $(0.016)$ & $(0.009)$ \\
Children 5+ & 0.159 & -0.11 & 0.108 & -0.076 \\
& $(0.026)$ & $(0.018)$ & $(0.024)$ & $(0.013)$ \\
Middle regions & 0.106 & -0.019 & 0.111 & -0.027 \\
& $(0.033)$ & $(0.023)$ & $(0.033)$ & $(0.027)$ \\
Southern regions & 0.117 & -0.01 & 0.118 & 0.004 \\
& $(0.027)$ & $(0.019)$ & $(0.029)$ & $(0.02)$ \\
German00 & 0.089 & 0.05 & -0.032 & 0.179 \\
German10 & $(0.098)$ & $(0.076)$ & $(0.097)$ & $(0.089)$ \\
& 0.053 & -0.052 & 0.023 & 0.011 \\
German01 & $(0.052)$ & $(0.046)$ & $(0.056)$ & $(0.063)$ \\
& 0.115 & -0.12 & 0.035 & -0.08 \\
Cohort 1931-45 & $(0.061)$ & $(0.05)$ & $(0.062)$ & $(0.053)$ \\
& 0.067 & 0.019 & 0.002 & -0.000 \\
Cohort 1946-55 & $(0.059)$ & $(0.042)$ & $(0.066)$ & $(0.05)$ \\
& 0.053 & 0.016 & 0.014 & 0.014 \\
Cohort 1966-79 & $(0.036)$ & $(0.026)$ & $(0.04)$ & $(0.03)$ \\
& -0.052 & -0.034 & -0.114 & -0.01 \\
Intercept & $(0.044)$ & $(0.029)$ & $(0.051)$ & $(0.032)$ \\
& 0.488 & 0.408 & 0.8 & 0.039 \\
Wald test $\hat{\lambda}_{i t}$ & $(0.412)$ & $(0.283)$ & $(0.425)$ & $(0.296)$ \\
P-value & 36.461 & 31.775 & 20.602 & 39.982 \\
Wald test $\bar{z}_{i t}$ & 0.019 & 0.062 & 0.483 & 0.007 \\
P-value & 21.05 & 26.105 & 23.813 & 28.003 \\
Sargan's test & 0.033 & 0.006 & 0.014 & 0.003 \\
P-Value & & 45.517 & & 43.039 \\
& & 0.654 & & 0.747 \\
\hline
\end{tabular}

Note: Asymptotic standard errors are in parentheses. 
Table 7: The effects of married life on female domestic and market work hours - Pooled

GMM estimates, marriage is exogenous

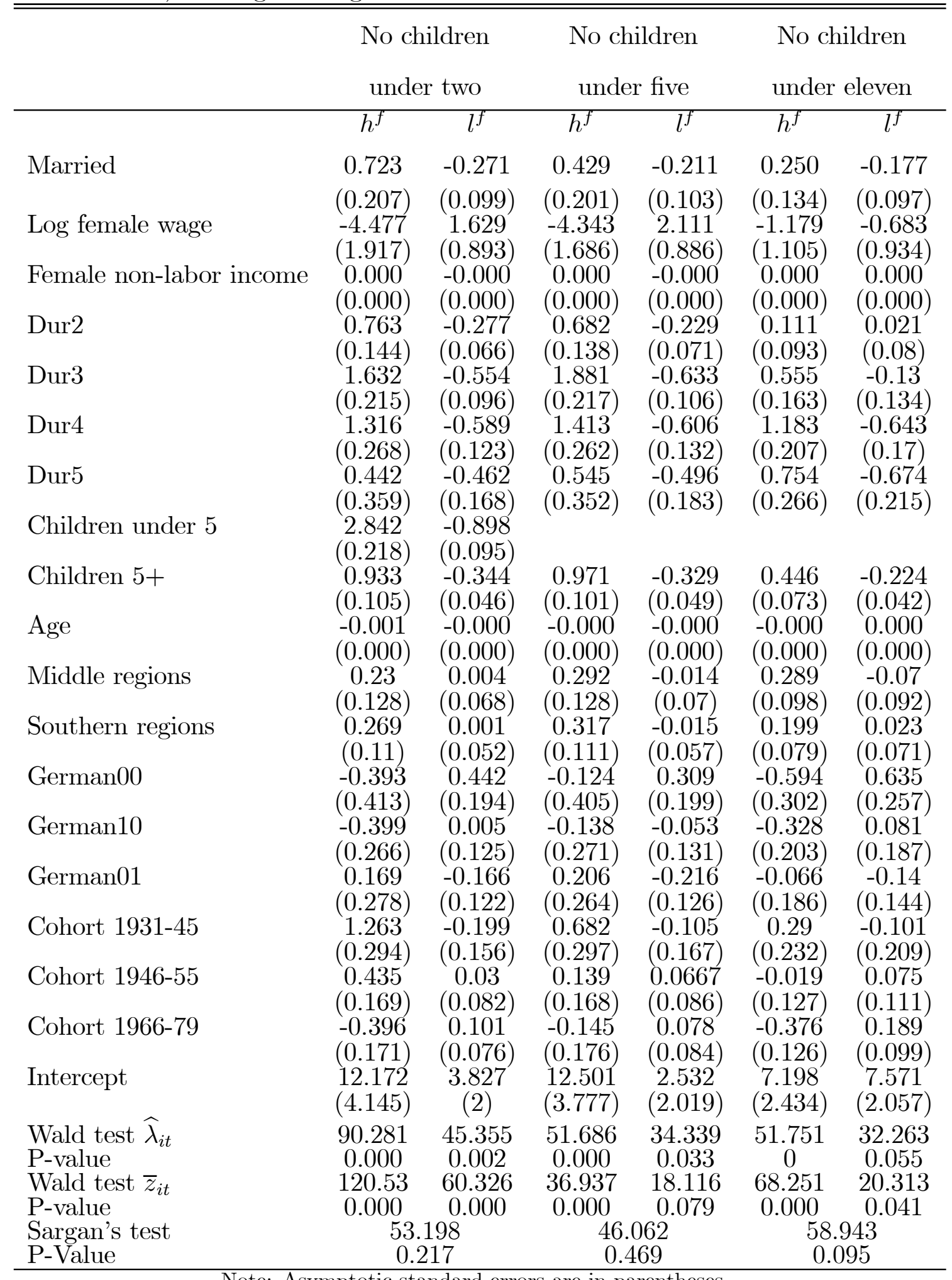

Note: Asymptotic standard errors are in parentheses. 
Table 8: Female wage elasticities of labor supply

\begin{tabular}{lccc}
\hline \hline & Estimates & Asymptotic Std. Err. & P-Values \\
\hline Estimated wage elasticity of the female & domestic labor supply & \\
Sample with no children under two & -1.119 & 0.479 & 0.019 \\
Sample with no children under five & -1.086 & 0.422 & 0.009 \\
Sample with no children under eleven & -.393 & 0.369 & 0.286 \\
\multicolumn{5}{l}{} \\
Estimated wage elasticity of the female market labor supply & \\
Sample with no children under two & 0.343 & 0.188 & 0.068 \\
Sample with no children under five & 0.424 & 0.178 & 0.017 \\
Sample with no children under eleven & -.126 & 0.173 & 0.465 \\
\hline
\end{tabular}

Notes: Elasticities are computed at the median. Marriage is assumed to be exogenous. 
Table 9: The effects of married life on female domestic and market work hours - Pooled GMM estimates, marriage is endogenous

\begin{tabular}{|c|c|c|c|c|c|c|}
\hline & \multicolumn{2}{|c|}{$\begin{array}{l}\text { No children } \\
\text { under two }\end{array}$} & \multicolumn{2}{|c|}{$\begin{array}{l}\text { No children } \\
\text { under five }\end{array}$} & \multicolumn{2}{|c|}{$\begin{array}{l}\text { No children } \\
\text { under eleven }\end{array}$} \\
\hline & $h^{f}$ & $l^{f}$ & $h^{f}$ & $l^{f}$ & $h^{f}$ & $l^{f}$ \\
\hline Married & $\begin{array}{l}7.229 \\
(0.73)\end{array}$ & $\begin{array}{l}-2.241 \\
(0.342)\end{array}$ & $\begin{array}{c}6.852 \\
(0.757)\end{array}$ & $\begin{array}{l}-2.366 \\
(0.372)\end{array}$ & $\begin{array}{c}2.847 \\
(0.629)\end{array}$ & $\begin{array}{c}-1.075 \\
(0.391)\end{array}$ \\
\hline Log female wage & $\begin{array}{c}-0.796 \\
(1.89)\end{array}$ & $\begin{array}{c}0.559 \\
(0.853)\end{array}$ & $\begin{array}{l}-1.247 \\
(1.561)\end{array}$ & $\begin{array}{c}0.712 \\
(0.811)\end{array}$ & $\begin{array}{l}0.316 \\
(1.16)\end{array}$ & $\begin{array}{c}-0.69 \\
(0.913)\end{array}$ \\
\hline Female non-labor income & $\begin{array}{c}0.000 \\
(0.000)\end{array}$ & $\begin{array}{c}0.000 \\
(0.000)\end{array}$ & $\begin{array}{c}0.000 \\
(0.000)\end{array}$ & $\begin{array}{c}0.000 \\
(0.000)\end{array}$ & $\begin{array}{c}0.000 \\
(0.000)\end{array}$ & $\begin{array}{c}0.000 \\
(0.000)\end{array}$ \\
\hline Children under 5 & $\begin{array}{c}2.699 \\
(0.226)\end{array}$ & $\begin{array}{l}-0.865 \\
(0.099)\end{array}$ & & & & \\
\hline Children $5+$ & $\begin{array}{c}1.103 \\
(0.103)\end{array}$ & $\begin{array}{l}-0.399 \\
(0.045)\end{array}$ & $\begin{array}{c}1.12 \\
(0.098)\end{array}$ & $\begin{array}{c}-0.386 \\
(0.046)\end{array}$ & $\begin{array}{c}0.488 \\
(0.078)\end{array}$ & $\begin{array}{l}-0.261 \\
(0.044)\end{array}$ \\
\hline Female age & $\begin{array}{c}-0.002 \\
(0.000)\end{array}$ & $\begin{array}{c}0.000 \\
(0.000)\end{array}$ & $\begin{array}{l}-0.001 \\
(0.000)\end{array}$ & $\begin{array}{c}0.000 \\
(0.000)\end{array}$ & $\begin{array}{l}-0.001 \\
(0.000)\end{array}$ & $\begin{array}{r}-0.000 \\
(0.000)\end{array}$ \\
\hline Middle regions & $\begin{array}{c}0.506 \\
(0.144)\end{array}$ & $\begin{array}{c}-0.082 \\
(0.075)\end{array}$ & $\begin{array}{c}0.528 \\
(0.143)\end{array}$ & $\begin{array}{l}-0.095 \\
(0.079)\end{array}$ & $\begin{array}{c}0.429 \\
(0.111)\end{array}$ & $\begin{array}{c}-0.11 \\
(0.094)\end{array}$ \\
\hline Southern regions & $\begin{array}{c}0.363 \\
(0.118)\end{array}$ & $\begin{array}{c}-0.02 \\
(0.059)\end{array}$ & $\begin{array}{c}0.364 \\
(0.119)\end{array}$ & $\begin{array}{c}-0.015 \\
(0.064)\end{array}$ & $\begin{array}{c}0.251 \\
(0.092)\end{array}$ & $\begin{array}{c}0.008 \\
(0.074)\end{array}$ \\
\hline German00 & $\begin{array}{c}-1.26 \\
(0.458)\end{array}$ & $\begin{array}{c}0.663 \\
(0.215)\end{array}$ & $\begin{array}{l}-1.178 \\
(0.455)\end{array}$ & $\begin{array}{c}0.702 \\
(0.226)\end{array}$ & $\begin{array}{l}-1.029 \\
(0.335)\end{array}$ & $\begin{array}{c}0.763 \\
(0.256)\end{array}$ \\
\hline German10 & $\begin{array}{c}-0.227 \\
(0.318)\end{array}$ & $\begin{array}{c}-0.032 \\
(0.152)\end{array}$ & $\begin{array}{l}-0.201 \\
(0.316)\end{array}$ & $\begin{array}{c}-0.021 \\
(0.163)\end{array}$ & $\begin{array}{l}-0.381 \\
(0.235)\end{array}$ & $\begin{array}{c}0.125 \\
(0.194)\end{array}$ \\
\hline German01 & $\begin{array}{c}-0.067 \\
(0.316)\end{array}$ & $\begin{array}{l}-0.109 \\
(0.132)\end{array}$ & $\begin{array}{l}-0.039 \\
(0.311)\end{array}$ & $\begin{array}{l}-0.106 \\
(0.138)\end{array}$ & $\begin{array}{l}-0.146 \\
(0.217)\end{array}$ & $\begin{array}{l}-0.115 \\
(0.143)\end{array}$ \\
\hline Cohort 1931-45 & $\begin{array}{c}1.072 \\
(0.295)\end{array}$ & $\begin{array}{l}-0.219 \\
(0.169)\end{array}$ & $\begin{array}{c}0.653 \\
(0.302)\end{array}$ & $\begin{array}{l}-0.219 \\
(0.18)\end{array}$ & $\begin{array}{c}0.318 \\
(0.258)\end{array}$ & $\begin{array}{l}-0.153 \\
(0.216)\end{array}$ \\
\hline Cohort 1946-55 & $\begin{array}{c}0.346 \\
(0.172)\end{array}$ & $\begin{array}{l}0.025 \\
(0.09)\end{array}$ & $\begin{array}{c}0.173 \\
(0.173)\end{array}$ & $\begin{array}{c}-0.002 \\
(0.096)\end{array}$ & $\begin{array}{c}0.019 \\
(0.142)\end{array}$ & $\begin{array}{c}0.027 \\
(0.116)\end{array}$ \\
\hline Cohort 1966-79 & $\begin{array}{c}-0.078 \\
(0.208)\end{array}$ & $\begin{array}{l}0.038 \\
(0.09)\end{array}$ & $\begin{array}{c}0.15 \\
(0.218)\end{array}$ & $\begin{array}{c}0.011 \\
(0.101)\end{array}$ & $\begin{array}{l}-0.197 \\
(0.164)\end{array}$ & $\begin{array}{c}0.087 \\
(0.114)\end{array}$ \\
\hline Intercept & $\begin{array}{c}3.845 \\
(4.258)\end{array}$ & $\begin{array}{c}6.333 \\
(1.974)\end{array}$ & $\begin{array}{c}5.107 \\
(3.678)\end{array}$ & $\begin{array}{c}5.64 \\
(1.916)\end{array}$ & $\begin{array}{c}3.656 \\
(2.558)\end{array}$ & $\begin{array}{c}7.599 \\
(2.003)\end{array}$ \\
\hline test: $\widehat{\lambda}_{i t}$ & 122.552 & 64.247 & 74.813 & 49.837 & 50.124 & 35.57 \\
\hline & & & & & & 0.024 \\
\hline Wald test: $\bar{z}_{i t}$ & 108.813 & 16.868 & 72.813 & 12.441 & 55.569 & 19.806 \\
\hline & 0.000 & 0.155 & 0.000 & 0.331 & 0.000 & 0.048 \\
\hline $\begin{array}{l}\text { Sargan's test } \\
\text { P-Value }\end{array}$ & $\begin{array}{r}66 . \\
0.0\end{array}$ & 16 & & 152 & & \\
\hline
\end{tabular}

Note: Asymptotic standard errors are in parentheses. 
Table 10: The effects of marriage on female and male domestic and market work hours Pooled GMM estimates, marriage is exogenous

\begin{tabular}{|c|c|c|c|c|}
\hline & \multicolumn{4}{|c|}{ No children under two } \\
\hline & $h^{f}$ & $l^{f}$ & $h^{m}$ & $l^{m}$ \\
\hline \multirow[t]{2}{*}{ Married } & 0.631 & -0.262 & 0.116 & 0.156 \\
\hline & $(0.204)$ & $(0.098)$ & $(0.125)$ & $(0.087)$ \\
\hline \multirow[t]{2}{*}{ Log female wage } & -3.535 & 1.368 & -1.645 & -0.662 \\
\hline & $(1.949)$ & $(0.942)$ & $(1.233)$ & $(0.801)$ \\
\hline \multirow{2}{*}{ Log male wage } & 4.431 & -0.96 & -0.098 & 1.882 \\
\hline & $(1.296)$ & $(0.623)$ & $(0.823)$ & $(0.543)$ \\
\hline Non-labor income & 0.0183 & 0.006 & 0.071 & -0.02 \\
\hline \multirow{2}{*}{ Dur2 } & $\begin{array}{l}(0.042) \\
0.695\end{array}$ & $\begin{array}{l}(0.019) \\
-0.261\end{array}$ & $\begin{array}{l}(0.054) \\
0.443\end{array}$ & $\begin{array}{l}(0.018) \\
-0.034\end{array}$ \\
\hline & $(0.131)$ & $(0.066)$ & $(0.087)$ & $(0.063)$ \\
\hline \multirow[t]{2}{*}{ Dur3 } & 1.4 & -0.503 & 0.719 & -0.249 \\
\hline & $(0.214)$ & $(0.105)$ & $(0.131)$ & $(0.093)$ \\
\hline \multirow[t]{2}{*}{ Dur4 } & 1.137 & -0.535 & 0.528 & -0.136 \\
\hline & $(0.266)$ & $(0.137)$ & $(0.164)$ & $(0.117)$ \\
\hline \multirow[t]{2}{*}{ Dur5 } & 0.266 & -0.411 & 0.22 & -0.125 \\
\hline & $(0.336)$ & $(0.175)$ & $(0.214)$ & $(0.149)$ \\
\hline \multirow[t]{2}{*}{ Children under 5} & 2.966 & -0.938 & 0.98 & 0.068 \\
\hline & $(0.214)$ & $(0.098)$ & $(0.139)$ & $(0.084)$ \\
\hline \multirow{2}{*}{ Children 5+ } & 1.009 & -0.37 & 0.175 & -0.000 \\
\hline & $(0.106)$ & $(0.05)$ & $(0.068)$ & $(0.042)$ \\
\hline \multirow{2}{*}{ Middle regions } & 0.242 & -0.012 & -0.1 & -0.026 \\
\hline & $(0.129)$ & $(0.069)$ & $(0.08)$ & $(0.054)$ \\
\hline \multirow[t]{2}{*}{ Southern regions } & 0.239 & 0.007 & -0.081 & -0.028 \\
\hline & $(0.105)$ & $(0.052)$ & $(0.065)$ & $(0.043)$ \\
\hline \multirow{2}{*}{ German00 } & -0.263 & 0.428 & -0.089 & 0.385 \\
\hline & $(0.433)$ & $(0.208)$ & $(0.281)$ & $(0.168)$ \\
\hline \multirow[t]{2}{*}{ German10 } & -0.276 & -0.026 & -0.174 & 0.199 \\
\hline & $(0.255)$ & $(0.126)$ & $(0.167)$ & $(0.091)$ \\
\hline \multirow[t]{2}{*}{ German01 } & 0.285 & -0.196 & -0.042 & 0.276 \\
\hline & $(0.286)$ & $(0.13)$ & & $(0.116)$ \\
\hline \multirow{2}{*}{ Cohort 1931-45 } & 1.111 & -0.148 & 0.18 & -0.098 \\
\hline & $(0.281)$ & $(0.154)$ & $(0.174)$ & $(0.118)$ \\
\hline \multirow[t]{2}{*}{ Cohort 1946-55 } & 0.391 & 0.035 & 0.017 & 0.031 \\
\hline & $(0.159)$ & $(0.08)$ & $(0.101)$ & $(0.062)$ \\
\hline \multirow[t]{2}{*}{ Cohort 1966-79 } & -0.351 & 0.085 & -0.102 & 0.066 \\
\hline & $(0.163)$ & $(0.074)$ & $(0.102)$ & $(0.068)$ \\
\hline \multirow[t]{2}{*}{ Age } & -0.001 & -0.000 & -0.000 & -0.000 \\
\hline & $(0.000)$ & $(0.000)$ & $(0.000)$ & $(0.000)$ \\
\hline Intercept & 0.89 & $\begin{array}{c}6.26 \\
(1058)\end{array}$ & $\begin{array}{l}6.568 \\
(2.409)\end{array}$ & 2.049 \\
\hline Wald test $\hat{\lambda}_{i t}$ & 101.364 & 41.591 & 128.051 & 42.965 \\
\hline P-value & 0.000 & 0.005 & 0.000 & 0.003 \\
\hline Wald test $\bar{z}_{i t}$ & 136.553 & 62.038 & 56.806 & 32.776 \\
\hline P-value & 0.000 & 0.000 & 0.000 & 0.001 \\
\hline Sargan's test & & 102 & 681 & \\
\hline P-Value & & & & \\
\hline
\end{tabular}


Table 11: Female and male wage elasticities of labor supply

\begin{tabular}{lccc}
\hline \hline & Estimates & Asymptotic Std. Err. & P-Values \\
\hline Estimated wage elasticity of the female domestic labor supply & \\
Sample with no children under two & -.884 & 0.487 & 0.069 \\
Sample with no children under five & -.983 & 0.454 & 0.030
\end{tabular}

Estimated cross wage elasticity of the female domestic labor supply

$\begin{array}{llll}\text { Sample with no children under two } & 1.108 & 0.324 & 0.001\end{array}$

$\begin{array}{llll}\text { Sample with no children under five } & 1.302 & 0.336 & 0.000\end{array}$

Estimated wage elasticity of the female market labor supply

$\begin{array}{llll}\text { Sample with no children under two } & 0.288 & 0.198 & 0.147\end{array}$

$\begin{array}{llll}\text { Sample with no children under five } & 0.405 & 0.184 & 0.028\end{array}$

Estimated cross wage elasticity of the female market labor supply

$\begin{array}{llll}\text { Sample with no children under two } & -.202 & 0.131 & 0.124\end{array}$

$\begin{array}{llll}\text { Sample with no children under five } & -.259 & 0.130 & 0.047\end{array}$

Estimated wage elasticity of the male domestic labor supply

$\begin{array}{llll}\text { Sample with no children under two } & -.049 & 0.411 & 0.905\end{array}$

$\begin{array}{llll}\text { Sample with no children under five } & 0.340 & 0.353 & 0.335\end{array}$

Estimated cross wage elasticity of the male domestic labor supply

$\begin{array}{llll}\text { Sample with no children under two } & -.823 & 0.617 & 0.182\end{array}$

$\begin{array}{llll}\text { Sample with no children under five } & -.126 & 0.995 & 0.899\end{array}$

Estimated wage elasticity of the male market labor supply

$\begin{array}{llll}\text { Sample with no children under two } & 0.331 & 0.096 & 0.001\end{array}$

$\begin{array}{llll}\text { Sample with no children under five } & 0.319 & 0.103 & 0.002\end{array}$

Estimated cross wage elasticity of the male market labor supply

$\begin{array}{llll}\text { Sample with no children under two } & -0.116 & 0.141 & 0.408\end{array}$

Sample with no children under five $\quad 0.007 \quad 0.138 \quad 0.959$

Notes: Elasticities are computed at the median. Marriage is assumed to be exogenous. 
Table 12: The effects of marriage on female and male domestic and market work hours Pooled GMM estimates, marriage is endogenous

\begin{tabular}{|c|c|c|c|c|}
\hline & \multicolumn{4}{|c|}{ No children under two } \\
\hline & $h^{f}$ & $l^{f}$ & $h^{m}$ & $l^{m}$ \\
\hline \multirow[t]{2}{*}{ Married } & 6.831 & -1.982 & 2.293 & 0.109 \\
\hline & $(0.801)$ & $(0.377)$ & $(0.414)$ & $(0.269)$ \\
\hline \multirow[t]{2}{*}{ Log female wage } & -1.618 & 1.144 & -0.448 & -0.974 \\
\hline & $(2.023)$ & $(0.923)$ & $(1.125)$ & $(0.717)$ \\
\hline \multirow[t]{2}{*}{ Log male wage } & 2.893 & -1.101 & -0.553 & 1.212 \\
\hline & $(1.433)$ & $(0.663)$ & $(0.832)$ & $(0.553)$ \\
\hline \multirow[t]{2}{*}{ Non-labor income } & -0.042 & 0.022 & 0.05 & -0.017 \\
\hline & $(0.043)$ & $(0.02)$ & $(0.028)$ & $(0.017)$ \\
\hline \multirow[t]{2}{*}{ Children under 5} & 2.813 & -0.91 & 0.914 & 0.158 \\
\hline & $(0.229)$ & $(0.101)$ & $(0.135)$ & $(0.08)$ \\
\hline \multirow{2}{*}{ Children $5+$} & 1.114 & -0.403 & 0.247 & -0.013 \\
\hline & $(0.11)$ & $(0.049)$ & $(0.06)$ & $(0.037)$ \\
\hline \multirow[t]{2}{*}{ Middle regions } & 0.449 & -0.061 & -0.022 & -0.018 \\
\hline & $(0.149)$ & $(0.075)$ & $(0.082)$ & $(0.053)$ \\
\hline \multirow[t]{2}{*}{ Southern regions } & 0.334 & -0.013 & -0.057 & -0.006 \\
\hline & $(0.118)$ & $(0.057)$ & $(0.063)$ & $(0.041)$ \\
\hline \multirow[t]{2}{*}{ German00 } & -0.929 & 0.502 & -0.418 & 0.344 \\
\hline & $(0.493)$ & $(0.222)$ & $(0.276)$ & $(0.162)$ \\
\hline \multirow[t]{2}{*}{ German10 } & -0.243 & -0.011 & -0.184 & 0.26 \\
\hline & $(0.316)$ & $(0.142)$ & $(0.175)$ & $(0.091)$ \\
\hline \multirow[t]{2}{*}{ German01 } & 0.166 & -0.216 & -0.161 & 0.249 \\
\hline & $(0.329)$ & $(0.137)$ & $(0.186)$ & $(0.109)$ \\
\hline \multirow[t]{2}{*}{ Cohort 1931-45 } & 0.934 & -0.169 & 0.075 & -0.111 \\
\hline & $(0.298)$ & $(0.163)$ & $(0.164)$ & $(0.111)$ \\
\hline \multirow[t]{2}{*}{ Cohort 1946-55 } & 0.329 & 0.022 & -0.041 & 0.021 \\
\hline & $(0.17)$ & $(0.085)$ & $(0.098)$ & $(0.059)$ \\
\hline \multirow[t]{2}{*}{ Cohort 1966-79 } & -0.081 & 0.046 & -0.005 & 0.079 \\
\hline & $(0.204)$ & $(0.085)$ & $(0.105)$ & $(0.067)$ \\
\hline \multirow[t]{2}{*}{ Age } & -0.002 & 0.000 & -0.000 & -0.000 \\
\hline & $(0.000)$ & $(0.000)$ & $(0.000)$ & $(0.000)$ \\
\hline \multirow[t]{2}{*}{ Intercept } & -1.697 & 7.671 & 4.454 & 4.77 \\
\hline & $(4.057)$ & (1.937) & $(2.325)$ & $(1.459)$ \\
\hline Wald test $\widehat{\lambda}_{i t}$ & 120.481 & 51.919 & 128.912 & 47.715 \\
\hline P-value & 0.000 & 0.000 & 0.000 & 0.001 \\
\hline Wald test $\widehat{z}_{i t}$ & 116.848 & 21.15 & 78.424 & 26.223 \\
\hline P-value & 0.000 & 0.048 & 0.000 & 0.010 \\
\hline Sargan's test & \multicolumn{4}{|c|}{119.711} \\
\hline P-Value & \multicolumn{4}{|c|}{0.028} \\
\hline
\end{tabular}




\section{Appendix A}

Here we derive the GMM estimator and its standard errors for a general model that controls for unobserved heterogeneity and sample selection bias. We begin with some notation. For couple $i$ at period $t$ we have a joint observation on $\left(Y_{i t}, X_{i t}\right)$, where $Y_{i t}=\left(\begin{array}{ccc}Y_{1 i t} & & \\ & \ddots & \\ & & Y_{\text {Git }}\end{array}\right)$ and $X_{i t}=\left(\begin{array}{ccc}X_{1 i t} & \\ & \ddots & \\ & & X_{\text {Git }}\end{array}\right)$ are bloc-diagonal matrices that stand for the $G$ regressands $Y_{i t}^{1}, \ldots, Y_{i t}^{G}$, and the $G$ vectors of regressors

$$
X_{i t}^{1}, \ldots, X_{i t}^{G} \text {, respec-tively. }
$$

The second-step system has the form:

$$
Y_{i t}=X_{i t} \theta+e_{i t}=\widehat{X}_{i t} \theta+\left(X_{i t}-\widehat{X}_{i t}\right) \theta+e_{i t},
$$

where $\widehat{X}_{i t}$ is the bloc-diagonal matrix of regressors including the generated inverse Mill's ratios from the first-step probit estimation, $\theta=\left(\theta_{1}^{\prime}, \ldots, \theta_{G}^{\prime}\right)^{\prime}$ is the vector of interest, and $e_{i t}$ is a $G$-vector of disturbance terms.

Let $\widehat{Z}_{i t}$ the vector of instruments that include the generated inverse Mill's ratios, and $\pi_{t}$ the vector of unknown coefficients of the first-step probit equation. For the Fixed Effect model, we have $Y_{i t}=y_{i t}-\bar{y}_{i}, \widehat{X}_{i t}=\left(x_{i t}-\bar{x}_{i}, \widehat{\lambda}_{i t}-\overline{\widehat{\lambda}}_{i}\right)$ and $\widehat{Z}_{i t}=\widehat{z}_{i t}-\overline{\widehat{z}}_{i}$ whereas $Y_{i t}=y_{i t}$, $\widehat{X}_{g i t}=\left(\alpha_{g}, x_{g i t}, \bar{z}_{i}, \widehat{\lambda}_{i t}\right)$ and $\widehat{Z}_{i t}=\widehat{z}_{i t}$ for the Pooled model.

The GMM estimator of (11) on the selected sample is then given by:

$$
\widehat{\theta}=\left[C^{\prime} W^{-1} C\right]^{-1} C^{\prime} W^{-1} E,
$$

where $C$ is a bloc-diagonal matrix with $C_{g}=N^{-1} \sum_{i=1}^{N} \sum_{t=1}^{T} s_{i t} \widehat{X}_{g i t}^{\prime} \widehat{Z}_{i t}$ on the diagonal, $E$ is a stacked vector of elements $N^{-1} \sum_{i=1}^{N} \sum_{t=1}^{T} s_{i t} \widehat{Z}_{i t}^{\prime} y_{g i t}$, and $W$ is a bloc-diagonal matrix with $N^{-1} \sum_{i=1}^{N} \sum_{t=1}^{T} s_{i t} \widehat{Z}_{i t}^{\prime} \widehat{Z}_{i t}$ on the diagonal, for $g=1, \ldots, G$.

We now turn to the asymptotic variance estimator of $\widehat{\theta}$. Plugging equation (11) in (12) we can write:

$$
\sqrt{N}(\widehat{\theta}-\theta)=\left[C^{\prime} W^{-1} C\right]^{-1} C^{\prime} W^{-1} A,
$$


where $A=\left(N^{-1 / 2} \sum_{i=1}^{N} \sum_{t=1}^{T} s_{i t} \widehat{Z}_{G i t}^{\prime}\left[\left(X_{i t}-\widehat{X}_{i t}\right) \theta+e_{i t}\right]\right)$, with $\widehat{Z}_{G i t}^{\prime}$ an appropriate stack of $\widehat{Z}_{i t}^{\prime}$ to have compatible dimensions. ${ }^{20}$

The term $\left(X_{i t}-\widehat{X}_{i t}\right) \theta$ in $A$ can be approximated to first order around $\pi=\widehat{\pi}$, the estimates of the probit equation, by the following expression:

$$
\widehat{X}_{i t} \theta=X_{i t} \theta+\theta^{\prime} \nabla_{\pi} X_{i t}^{\prime}\left(\widehat{\pi}_{G}-\pi_{G}\right)+o_{p}(1)
$$

where $\nabla_{\pi} X_{i t}^{\prime}$ is the Jacobian of $X_{i t}^{\prime}$ with respect to $\pi$. Again, the vector $\widehat{\pi}_{G}-\pi_{G}$ is just a stack of $\widehat{\pi}-\pi$ to have compatible dimensions. Following Semykina and Wooldridge (2005), we write:

$$
\sqrt{N}(\widehat{\pi}-\pi)=N^{-1 / 2} \sum_{i=1}^{N} r_{i}(\pi)+o_{p}(1),
$$

where $r_{i}(\pi)$ is a term that depends on the expected hessian and scores of the probit log-likelihood.

Using some algebra it follows that:

$$
A \simeq N^{-1 / 2} \sum_{i=1}^{N}\left[\sum_{t=1}^{T} s_{i t} \widehat{Z}_{G i t}^{\prime} e_{i t}-F \sum_{i=1}^{N} r_{i}(\pi)\right]
$$

where $F=\left(\begin{array}{c}F_{1} \\ \vdots \\ F_{G}\end{array}\right)$, with $F_{g}=\frac{1}{N} \sum_{i=1}^{N} \sum_{t=1}^{T} s_{i t} \widehat{Z}_{i t}^{\prime} \theta_{g}^{\prime} \nabla_{\pi} X_{g i t}^{\prime}, g=1, \ldots, G$. The asymptotic variance estimator of $\widehat{\theta}$ is thus given by:

$$
\left[C^{\prime}\left(A^{\prime} A\right)^{-1} C\right]^{-1}
$$

In practice, the unknown term $e_{i t}, F$ and $r_{i}$ are replaced with their respective consistent estimators $\widehat{e}_{i t}=\left(y_{i t}-\widehat{X}_{i t} \widehat{\theta}\right), \widehat{F}_{g}=\left(N^{-1} \sum_{i=1}^{N} \sum_{t=1}^{T} s_{i t} \widehat{Z}_{i t}^{\prime} \widehat{\theta}_{g}^{\prime} \nabla_{\pi} \widehat{X}_{g i t}^{\prime}\right)$ and $\widehat{r}_{i}$. Let $q_{i t}=\left(\eta, z_{i t}, \bar{z}_{i}\right)$ the vector of regressors that appear in the first-step probit. Then,

$$
\widehat{r}_{i t}=\widehat{H}_{t}^{-1}\left\{\Phi\left(q_{i t} \widehat{\pi}_{t}\right)\left[1-\Phi\left(q_{i t} \widehat{\pi}_{t}\right)\right]\right\}^{-1} \phi\left(q_{i t} \widehat{\pi}_{t}\right) q_{i t}^{\prime}\left[s_{i t}-\Phi\left(q_{i t} \widehat{\pi}_{t}\right)\right],
$$

\footnotetext{
${ }^{20}$ For instance, $\widehat{Z}_{2 i t}^{\prime}=\left(\widehat{Z}_{i t}, \widehat{Z}_{i t}\right)^{\prime}$ for a two-equation system.
} 
where:

$$
\widehat{H}_{t}^{-1} \equiv \frac{1}{N}\left\{\Phi\left(q_{i t} \widehat{\pi}_{t}\right)\left[1-\Phi\left(q_{i t} \widehat{\pi}_{t}\right)\right]\right\}^{-1}\left[\phi\left(q_{i t} \widehat{\pi}_{t}\right)\right]^{2} q_{i t}^{\prime} q_{i t}
$$

is the consistent estimator of minus the expected Hessien (see Semykina and Wooldridge, 2005). For each couple $i$, the $\widehat{r}_{i t}$ are stacked to obtain the $\widehat{r}_{i}$ used in equation (13). The estimated variance estimator is therefore:

$$
\left[C^{\prime}\left(\widehat{A}^{\prime} \widehat{A}\right)^{-1} C\right]^{-1}
$$


Appendix B 
Table 13: The permanent effects of the transition to marriage on the female-to-male domestic and market work hours (log) ratios - Pooled GMM estimates, marriage is exogenous

\begin{tabular}{|c|c|c|c|c|c|c|}
\hline & \multicolumn{2}{|c|}{$\begin{array}{l}\text { No children } \\
\text { under two }\end{array}$} & \multicolumn{2}{|c|}{$\begin{array}{l}\text { No children } \\
\text { under five }\end{array}$} & \multicolumn{2}{|c|}{$\begin{array}{l}\text { No children } \\
\text { under eleven }\end{array}$} \\
\hline & $r^{1}=\frac{h^{f}}{h^{m}}$ & $r^{2}=\frac{l^{f}}{l^{m}}$ & $r^{1}=\frac{h^{f}}{h^{m}}$ & $r^{2}=\frac{l^{f}}{l^{m}}$ & $r^{1}=\frac{h^{f}}{h^{m}}$ & $r^{2}=\frac{l^{f}}{l^{m}}$ \\
\hline \multirow[t]{2}{*}{ Change } & 0.150 & -0.099 & 0.113 & -0.091 & 0.086 & -0.082 \\
\hline & $(0.049)$ & $(0.029)$ & $(0.049)$ & $(0.03)$ & $(0.048)$ & $(0.025)$ \\
\hline \multirow[t]{2}{*}{ Log wage ratio } & -1.026 & 0.69 & -0.946 & 0.633 & -0.293 & -0.099 \\
\hline & $(0.345)$ & $(0.219)$ & $(0.331)$ & $(0.211)$ & $(0.326)$ & $(0.195)$ \\
\hline \multirow[t]{2}{*}{ Non-labor income } & -0.021 & 0.005 & -0.017 & 0.005 & -0.028 & -0.005 \\
\hline & $(0.011)$ & $(0.006)$ & $(0.011)$ & $(0.007)$ & $(0.015)$ & $(0.009)$ \\
\hline \multirow[t]{2}{*}{ Dur2 } & 0.006 & -0.075 & -0.007 & -0.064 & -0.062 & -0.008 \\
\hline & $(0.033)$ & $(0.02)$ & $(0.034)$ & $(0.02)$ & $(0.037)$ & $(0.02)$ \\
\hline \multirow[t]{2}{*}{ Dur3 } & 0.025 & -0.09 & 0.063 & -0.105 & -0.036 & -0.014 \\
\hline & $(0.046)$ & $(0.03)$ & $(0.047)$ & $(0.03)$ & $(0.046)$ & $(0.029)$ \\
\hline \multirow[t]{2}{*}{ Dur4 } & 0.024 & -0.114 & 0.042 & -0.114 & 0.101 & -0.164 \\
\hline & $(0.059)$ & $(0.038)$ & $(0.059)$ & $(0.038)$ & $(0.059)$ & $(0.04)$ \\
\hline \multirow[t]{2}{*}{ Dur5 } & -0.014 & -0.078 & 0.014 & -0.08 & 0.089 & -0.161 \\
\hline & $(0.068)$ & $(0.042)$ & $(0.069)$ & $(0.043)$ & $(0.073)$ & $(0.05)$ \\
\hline \multirow[t]{2}{*}{ Children under 5} & 0.263 & -0.281 & & & & \\
\hline & $(0.05)$ & $(0.033)$ & & & & \\
\hline \multirow[t]{2}{*}{ Children 5+ } & 0.128 & -0.096 & 0.131 & -0.093 & 0.096 & -0.061 \\
\hline & $(0.024)$ & $(0.015)$ & $(0.023)$ & $(0.016)$ & $(0.022)$ & $(0.013)$ \\
\hline \multirow[t]{2}{*}{ Middle regions } & 0.072 & 0.01 & 0.088 & -0.004 & 0.101 & -0.016 \\
\hline & $(0.032)$ & $(0.022)$ & $(0.032)$ & $(0.022)$ & $(0.031)$ & $(0.026)$ \\
\hline \multirow[t]{2}{*}{ Southern regions } & 0.089 & 0.005 & 0.107 & 0.002 & 0.107 & 0.019 \\
\hline & $(0.025)$ & $(0.016)$ & $(0.025)$ & $(0.017)$ & $(0.027)$ & $(0.02)$ \\
\hline \multirow[t]{2}{*}{ German00 } & 0.116 & 0.03 & 0.136 & 0.021 & -0.023 & 0.166 \\
\hline & $(0.09)$ & $(0.069)$ & $(0.093)$ & $(0.071)$ & $(0.093)$ & $(0.086)$ \\
\hline \multirow[t]{2}{*}{ German10 } & -0.009 & -0.039 & 0.016 & -0.046 & -0.001 & 0.024 \\
\hline & $(0.05)$ & $(0.04)$ & $(0.049)$ & $(0.042)$ & $(0.052)$ & $(0.062)$ \\
\hline \multirow[t]{2}{*}{ German01 } & 0.127 & -0.11 & 0.117 & -0.109 & 0.036 & -0.076 \\
\hline & $(0.059)$ & $(0.046)$ & $(0.06)$ & $(0.047)$ & $(0.059)$ & $(0.051)$ \\
\hline \multirow[t]{2}{*}{ Cohort 1931-45 } & 0.146 & -0.017 & 0.107 & -0.018 & -0.011 & 0.0184 \\
\hline & $(0.065)$ & $(0.044)$ & $(0.064)$ & $(0.043)$ & $(0.065)$ & $(0.051)$ \\
\hline \multirow[t]{2}{*}{ Cohort 1946-55 } & 0.081 & 0.006 & 0.064 & 0.008 & -0.001 & 0.026 \\
\hline & $(0.036)$ & $(0.024)$ & $(0.036)$ & $(0.024)$ & $(0.037)$ & $(0.029)$ \\
\hline \multirow[t]{2}{*}{ Cohort 1966-79 } & -0.104 & 0.012 & -0.09 & -0.004 & -0.145 & 0.026 \\
\hline & $(0.039)$ & $(0.024)$ & $(0.041)$ & $(0.025)$ & $(0.046)$ & $(0.026)$ \\
\hline \multirow[t]{2}{*}{ Intercept } & 0.513 & 0.438 & 0.685 & 0.208 & 0.965 & -0.134 \\
\hline & $(0.378)$ & $(0.256)$ & $(0.372)$ & $(0.259)$ & $(0.382)$ & $(0.273)$ \\
\hline & \multicolumn{2}{|c|}{47.324} & \multicolumn{2}{|c|}{50.049} & \multicolumn{2}{|c|}{52.838} \\
\hline P-Value & \multicolumn{2}{|c|}{0.500} & \multicolumn{2}{|c|}{0.392} & & \\
\hline
\end{tabular}

Note: Asymptotic standard errors are in parentheses. 


\section{References}

[1] Anderberg, Dan, "Voluntary Income Sharing and the Desigt of Unemployment Insurance," Journal of Population Economics 16.(2003), 71-90.

[2] Apps, Patricia F., and Ray Rees, "Taxation and the Household," Journal of Public Economics 35:3 (1988), 355-369.

[3] Basu, Kaushik, "Gender and Say: A Model of Household Behaviour with Endogenously Determined Balance of Power," Economic Journal 116 (2006), 558-580.

[4] Becker, Gary, "A Theory of Marriage: Part I," Journal of Political Economy, 81:4 (1973), 813-846.

[5] Blundell R., P.-A. Chiappori, T. Magnac, and C. Meghir, "Collective Labour Supply: Heterogeneity and Nonparticipation," IZA Discussion Paper No. 1785 (2005).

[6] Blundell R., A. Duncan and C. Meghir, "Estimating Labor Supply Responses Using Tax Reforms," Econometrica 66:4 (1998), 827-861.

[7] Brien, M. J., L. A. Lillard and S. Stern, "Interrelated Family-Building Behaviors: Cohabitation, Marriage, and Nonmarital Conception," Demography 36:4 (1999), 535551.

[8] Brien, M. J., L. A. Lillard and S. Stern, "Cohabitation, Marriage, and Divorce in a Model of Match Quality," International Economic Review 47:2 (2006), 451-494.

[9] Browning, Martin, "Children and Household Economic Behavior," Journal of Economic Literature 30:3 (1992), 1434-1475.

[10] Browning, Martin, and Mette Gørtz, "Spending time and money within the household," Discussion Papers Series 288, University of Oxford, (2006).

[11] Bumpass, L.L., Sweet, J.A., "Cohabitation, marriage, and union stability: preliminary findings from NSFH2" NSFH Working Paper No. 65 (1995). 
[12] Chiappori, Pierre-André, "Rational Household Labor Supply," Econometrica 56:1 (1988), 63-90.

[13] Chiappori, P.-A., B. Fortin, and G. Lacroix, "Marriage Market, Divorce Legislation and Household Labour Supply," Journal of Political Economy 110:1 (2002), 37-72.

[14] Cohen, Philipp K., "Cohabitation and the Declining Marriage Premium for Men," Work and Occupations 29:3 (2002), 346-363.

[15] Couprie, Hélène, "Time allocation within the family: welfare implications of life in a couple," The Economic Journal (2007), forthcoming.

[16] Davies H., H. Joshi, M. Killingsworth and R. Peronaci, "How do couples spend their time? Hours of market and domestic, work time in British partnerships," in S. Gustafsson and D. Meulders (Eds.), Gender and the Labour Market: Econometric Evidence on Obstacles in Achieving Gender Equality (Basingstoke, Macmillan, 2000).

[17] DeLeire, Thomas, and Ariel Kalil, "How Do Cohabiting Couples With Children Spend Their Money?," Journal of Marriage and the Family 67:2 (2005), 286-295.

[18] Deutsches Jugendinstitut, "Zahlenspiegel. daten zu tageseinrichtungen für kinder" Fact book on daycare facilities for children, Muenchen, Germany: Deutsches Jugendinstitut (2002).

[19] Donni, Olivier, "Collective Female Labor Supply: Theory and Application," The Economic Journal (2007), forthcoming.

[20] Donni, Olivier, and Nicolas Moreau, "Collective Labor Supply: A Single-Equation Model and Some Evidence from French Data," Journal of Human Resources (2007), forthcoming.

[21] Gornick, Janet C., and Marcia K. Meyers, "Families That Work: Policies for Reconciling Parenthood and Employment" (New York: Russell Sage Foundation, 2003). 
[22] Gray, Jeffrey S., "The Fall in Men's Return to Marriage: Declining Productivity Effects or Changing Selection?," The Journal of Human Resources 22:3 (1997), 481504.

[23] Gustafsson, Siv, (1992). "Separate taxation and married women's labor supply. A comparison of West Germany and Sweden," Journal of Population Economics 5:1 (1992), 61-85.

[24] Kiker, B. F., and Ying Chun Ng, "A Simultaneous Equation Model of Spousal Time Allocation," Social Science Research 19 (1990), 132-152.

[25] Kooreman, Peter, and Arie Kapteyn, "A Disaggregated Analysis of the Allocation of Time Within the Household," The Journal of Political Economy 95:2 (1987), 223-249.

[26] Kotlikoff, Laurence J., and Avia Spivak, "The Family as an Incomplete Annunites Market," Journal of Political Economy 89:2 (1981), 372-391.

[27] Kyriazidou, E., "Estimation of a panel data sample selection model," Econometrica 65 (1997), 1335-1364.

[28] Laisney, F., M. Lechner, A. van Soest and G. Wagenhals, "A life cycle labour supply model with taxes estimated on German panel data," The Economic and Social Review 24 (1993), 335-369.

[29] Le Goff, Jean-Marie, "Cohabiting Unions in France and West Germany," Demographic Research 7:18 (2002), 593-624.

[30] Lillard, L. A., Brien, M. J., and S. Stern, "Premarital Cohabitation and Subsequent Marital Dissolution: A Matter of Self-Selection?," Demography 32:3 (1995), 437-457.

[31] Lundberg, Shelly, "Men in islands: Dealing with the family in empirical labor economics," Labor economics, 12:4 (2005), 591-612.

[32] Lundberg, Shelly, "Limits to Specialization: Efficiency and the Division of Labor in Modern Families," working paper university of Washington, (2002). 
[33] Lundberg, Shelly, "The Division of Labor Supply by new Parents: Does Child Gender Matter?," working paper university of Washington, (2005).

[34] Lundberg, Shelly, and Elaina Rose, "The effects of sons and daughters on men's labor supply and wages" The Review of Economic and Statistics 84:2 (2002), 251-268.

[35] Mamun, Arif, "Is There a Cohabitation Premium in Men?s Earnings?," Center for Research on Families, working Paper 2004-02 (2004).

[36] McConocha, Diane M., Shirlee A. Tully, and Carl H. Walther, "Household Money Management: Recognizing Nontraditional Couples," Journal of Consumer Affairs $27: 2$ (1993), 258-283.

[37] McElroy, Marjorie B., and Mary Jean Horney, "Nash-bargained household decisions: toward a Generalization of the Theory of Demand," International Economic Review, 22:2 (1981), 333-349.

[38] Nordblom, Katarina, "Cohabitation and Marriage in a Risky World," Review of Economics of the Household 2 (2004), 325-340.

[39] Mundlak, Y., "On the pooling of time series and cross section data," Econometrica 46 (1978), 69-85.

[40] Pencavel, John, "A life cycle perspective on changes in earnings inequality among married men and women," The Review of Economic and Statistics 88:2 (2006), 232242.

[41] Pollak, Robert A., and Michael L.Wachter, "The Relevance of the Household Production Function and Its Implications for the Allocation of Time," The Journal of Political Economy 83:2 (1975), 255-278.

[42] Rangel, Marcos A., "Alimony Rights and Intrahousehold Allocation of Resources: Evidence From Brazil," The Economic Journal 116: July, (2006), 627-658. 
[43] Semykina, Anastasia, and Jeffrey M. Wooldridge, "Estimating panel data models in the presence of endogeneity and selection: Theory and application," Working Paper Michigan State University (2005).

[44] South, Scott J., and Glenna Spitze, "Housework in marital and nonmarital households," American Sociological Review 59:3 (1994), 327-437.

[45] Steiner, Viktor, and Peter Jacobebbinghaus, "Reforming Social Welfare as We Know It? A Microsimulation Study for Germany," Working Paper (2003).

[46] Stintzing, Heike, "Constitutional values and social change - the case of german marital and family law," Institutional Journal of Law, Policy and the Family 13 (1999), 132-146.

[47] Stratton, Leslie S., "Examining the Wage Differential for Married and Cohabiting Men," Economic Inquiry 40:2 (2002), 199-212.

[48] Stratton, Leslie S., "The Degree of Intrahousehold Specialization in Housework and How Specialization Varies Across Couple Households," (2005), paper presented at the June 2005 SOLE Meetings.

[49] Van Der Klauuw, Wilbert, "Female Labour Supply and Marital Status Decisions: A Life Cycle-Model," The Review of Economic Studies 63:2 (1996), 199-235.

[50] Waite, Linda J., "Does Marriage matter?," Demography 32:4 (1995), 483-507.

[51] Wells, Robin, and Maria Maher, "Time and Surplus Allocation Within Marriage," working paper Massachusetts Institute of Technology (1998).

[52] Wrede, Matthias, "The Income Splitting Method: Is it Good for Both Marriage Partners?," German Economic Review 4(2): (2003), 203-216. 